OPEN ACCESS

Edited by:

Magali Araujo,

Georgetown University,

United States

Reviewed by:

Zaid A. Abassi,

Technion - Israel Institute of

Technology, Israel

Matthew Michael James Edey,

Hull and East Yorkshire Hospitals

NHS Trust, United Kingdom

*Correspondence:

Christos P. Argyropoulos

argchris@hotmail.com

Specialty section:

This article was submitted to Nephrology,

a section of the journal

Frontiers in Medicine

Received: 12 April 2017

Accepted: 26 May 2017

Published: 15 June 2017

Citation:

Argyropoulos CP, Chen SS, Ng Y-H, Roumelioti $M-E$, Shaffi $K$, Singh PP and Tzamaloukas AH (2017)

Rediscovering Beta-2 Microglobulin As a Biomarker across the Spectrum

of Kidney Diseases.

Front. Med. 4:73.

doi: $10.3389 /$ fmed.2017.00073

\section{Rediscovering Beta-2 Microglobulin As a Biomarker across the Spectrum of Kidney Diseases}

\author{
Christos P. Argyropoulos ${ }^{1 *}$, Shan Shan Chen ${ }^{1}$, Yue-Harn Ng ${ }^{1}$, Maria-Eleni Roumelioti', \\ Kamran Shaffi', Pooja P. Singh ${ }^{1}$ and Antonios H. Tzamaloukas ${ }^{1,2}$ \\ ${ }^{1}$ Nephrology Division, Department of Internal Medicine, University of New Mexico School of Medicine, Albuquerque, NM, \\ United States, ${ }^{2}$ Raymond G. Murphy VA Medical Center Albuquerque, Albuquerque, NM, United States
}

There is currently an unmet need for better biomarkers across the spectrum of renal diseases. In this paper, we revisit the role of beta-2 microglobulin $\left(\beta_{2} \mathrm{M}\right)$ as a biomarker in patients with chronic kidney disease and end-stage renal disease. Prior to reviewing the numerous clinical studies in the area, we describe the basic biology of $\beta_{2} \mathrm{M}$, focusing in particular on its role in maintaining the serum albumin levels and reclaiming the albumin in tubular fluid through the actions of the neonatal $\mathrm{Fc}_{\mathrm{c}}$ receptor. Disorders of abnormal $\beta_{2} \mathrm{M}$ function arise as a result of altered binding of $\beta_{2} \mathrm{M}$ to its protein cofactors and the clinical manifestations are exemplified by rare human genetic conditions and mice knockouts. We highlight the utility of $\beta_{2} \mathrm{M}$ as a predictor of renal function and clinical outcomes in recent large database studies against predictions made by recently developed whole body population kinetic models. Furthermore, we discuss recent animal data suggesting that contrary to textbook dogma urinary $\beta_{2} \mathrm{M}$ may be a marker for glomerular rather than tubular pathology. We review the existing literature about $\beta_{2} \mathrm{M}$ as a biomarker in patients receiving renal replacement therapy, with particular emphasis on large outcome trials. We note emerging proteomic data suggesting that $\beta_{2} \mathrm{M}$ is a promising marker of chronic allograft nephropathy. Finally, we present data about the role of $\beta_{2} \mathrm{M}$ as a biomarker in a number of non-renal diseases. The goal of this comprehensive review is to direct attention to the multifaceted role of $\beta_{2} \mathrm{M}$ as a biomarker, and its exciting biology in order to propose the next steps required to bring this recently rediscovered biomarker into the twenty-first century.

Keywords: beta-2 microglobulin, chronic kidney disease, biomarkers, kidney transplantation, pediatric nephrology, acute kidney injury, multiple myeloma, glomerular filtration rate

\section{INTRODUCTION}

Chronic kidney disease (CKD) is a common public health issue associated with astonishingly high cardiovascular (CV) morbidity and mortality and high costs, particularly for patients with diabetic nephropathy. Patients with renal failure on maintenance dialysis have excess mortality, that is, eight times higher than that of the general population (1). Most patients die due to CV events related to both traditional and non-traditional risk factors (2) and this is true for both predialysis and dialysis patients. Attempts to modify cardiorenal risk in CKD by intensive glycemic (3) or blood pressure (4, 5) control, or combined RAAS inhibition (6-8) had modest efficacy and serious adverse events. In 
light of these observations, it becomes imperative to acknowledge our lack of understanding of uremic toxicity and to reexamine assumptions about biological pathways that are potentially deranged in uremia. This understanding may then satisfy a significant unmet need for better biomarkers across the spectrum of CKD. Such markers may not only be used to risk stratify patients for future clinical studies, but may also suggest targets for future pharmacological interventions.

In this report, we aim to highlight the potential role of beta- 2 microglobulin $\left(\beta_{2} \mathrm{M}\right)$ as a marker and possibly a mediator of some of the complications of the uremic syndrome. The classical view of $\beta_{2} \mathrm{M}$ has been that the molecule is relevant to the pathophysiology of dialysis-related amyloidosis (DRA) (9-19), a truly multifactorial syndrome. The molecule itself was considered to be a relatively non-toxic uremic retention solute, whose importance as a non-creatinine $(\mathrm{Cr})$ renal filtration marker was overshadowed by cystatin, when the latter was chosen for investigation in the mid-1980s and 1990s (20-22). Nevertheless, there are compelling reasons to challenge this narrow view of $\beta_{2} \mathrm{M}$.

In this paper, we will first review the basic biology and rare genetic disorders (immunodeficiency 43, OMIM \#241600) associated with dysfunction of $\beta_{2} \mathrm{M}$. This overview sets the stage for reconsidering the role of $\beta_{2} \mathrm{M}$ by reviewing numerous studies published in the last 5 years. In particular, we will focus on recent reports examining the role of $\beta_{2} \mathrm{M}$ as a marker of renal filtration and outcomes in renal diseases across the spectrum of CKD to end-stage renal disease (ESRD) and kidney transplantation. We will also review data from non-renal diseases, a field that is usually ignored in articles focusing on nephrologists. However, this rapidly expanding literature sheds some light into the potential pathogenic role of $\beta_{2} \mathrm{M}$ in human disease. Due to space limitations, we will not cover the topic of $\beta_{2} \mathrm{M}$-related amyloidosis disorders, which extend all the way from rare familial non-neuropathic amyloidosis syndromes to DRA. This is a topic that has been recently reviewed both at the biochemical (23-26) and the clinical level $(10,11)$, with the early literature surveyed extensively more than 10 years ago (27).

In the concluding section of this review, we will attempt to synthetize the available data, informed by our analysis of the kinetics of $\beta_{2} \mathrm{M}$ and the associations between concentrations of this biomarker with outcomes. We hope that our reflections will provoke the readers to critically rethink their own assumptions about the utility of $\beta_{2} \mathrm{M}$, this easily measured, forgotten, and rediscovered protein that accumulates in renal insufficiency.

\section{$\beta_{2}$ M PHYSIOLOGY AND PATHOPHYSIOLOGY}

Beta-2 microglobulin was first discovered in 1964 in the urine of subjects with Wilson's disease or cadmium poisoning (28). It is a 100 -amino acid protein of relatively small molecular weight $(11,800 \mathrm{Da}$, size $11 \AA)$ and it is encoded by a gene in chromosome 15 in humans. The secondary structure of the molecule consists of two large beta sheets that are linked together by a single disulfide bond $(29,30)$. The tertiary structure of the molecule is thus similar to the constant domain of the immunoglobulins (Figure 1).

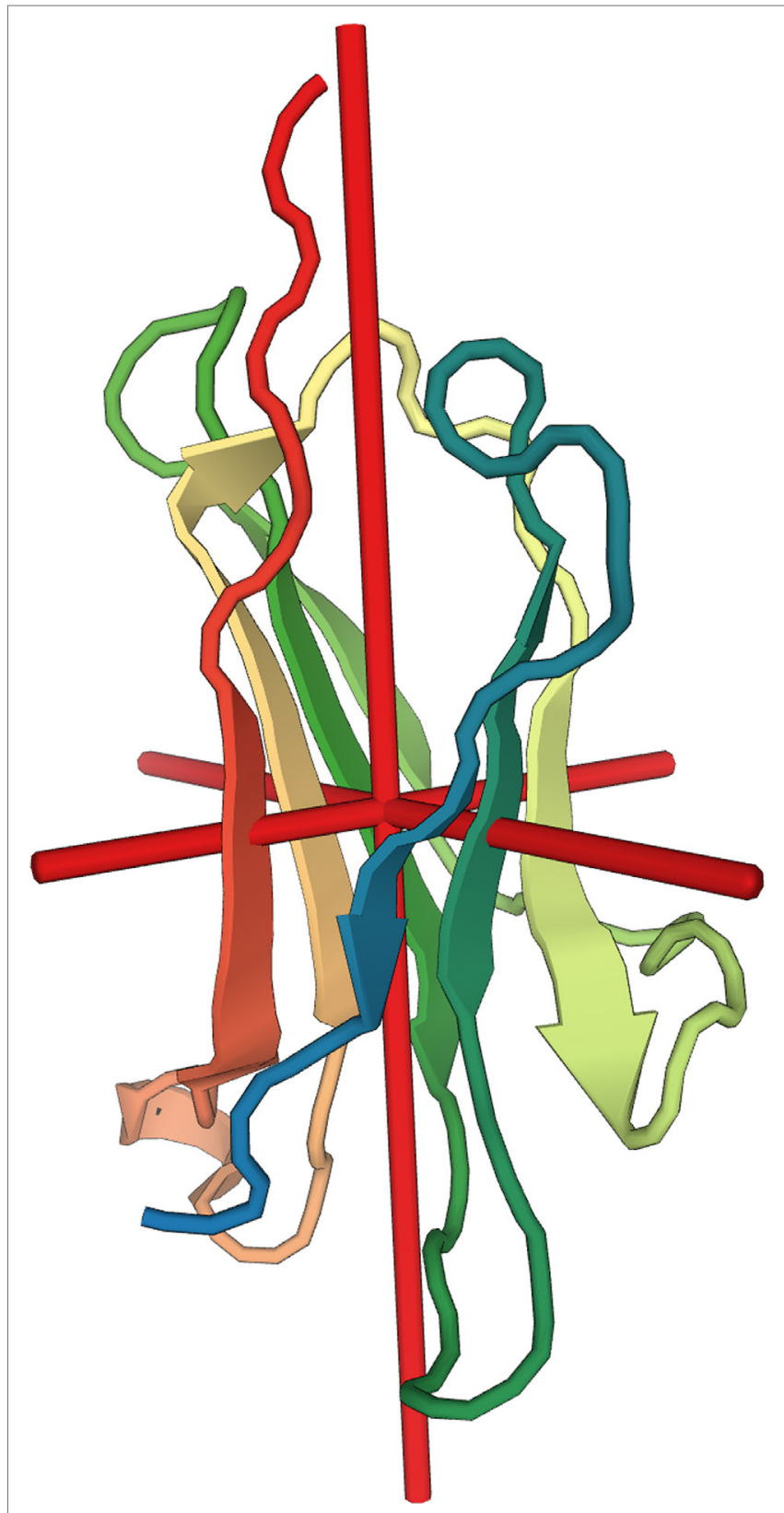

FIGURE 1 | Molecular structure of beta-2 microglobulin $\left(\beta_{2} \mathrm{M}\right)$. Depiction of the secondary structure of $\beta_{2} \mathrm{M}$ relative to the center of gravity of the molecule (red cross). X-ray diffraction at resolution of $1.13 \AA$ (30). Image rendered from the Protein Data Bank entry 2YXF.

In contrast to the immunoglobulins, $\beta_{2} \mathrm{M}$ does not form dimers but rather associates with the major histocompatibility complex I (MHC-I)/human leukocyte antigen I (HLA-I) on the surface of all nucleated cells. The interaction between $\beta_{2} \mathrm{M}$ with the alpha chain of the HLA-I is essential for antigen presentation $(31,32) . \beta_{2} \mathrm{M}$ also complexes with many non-classical MHC-I like molecules (MHC-Ib) such as CD1, MR1 (33), HLA-E, -F, -G $(34,35)$, neonatal Fc receptor (FcRn) (36-38), and HFE/HLA-H that are involved in mucosal immunity, tumor surveillance, 


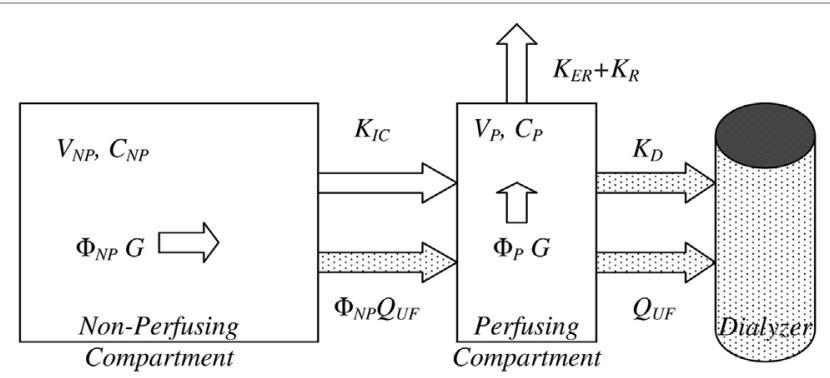

FIGURE 2 | Bicompartmental beta-2 microglobulin $\left(\beta_{2} \mathrm{M}\right)$ kinetics. Bicompartmental system describing $\beta_{2} \mathrm{M}$ kinetics consisting of a plasma/ perfusing $(\mathrm{P})$ and non-perfusing/non-plasma (NP) with additional material fluxes for patients during hemodialysis sessions (stippled shapes). In each compartment, the symbols $\mathrm{V}, \Phi$, and $\mathrm{C}$ denote the absolute and fractional volume of each compartment and the concentration of $\beta_{2} \mathrm{M}$, respectively. Generation $(\mathrm{G})$ takes place in both compartments, in direct proportion to their fractional volumes. $K_{D}, K_{E R}$, and $K_{R}$ are the dialyzer clearance, extrarenal, and residual renal clearances. Adapted from Supplementary Figure S1 of Ref. (117), reused under the Creative Commons CC BY license terms.

maternofetal immune tolerance, immunoglobulin and albumin homeostasis as well as iron metabolism. Disorders of $\beta_{2} \mathrm{M}$ function thus arise from interruption of its interaction with classical and non-classical MHC-I molecules. Their consequences can be anticipated from the normal function of the $\beta_{2} \mathrm{M}$ complexes. A thorough consideration of the entire spectrum of such disorders would by necessity encompass the entire complement of classical and non-classical MHC-I molecules and it is beyond the scope of this review (see $(34,39)$ and $(40)$ for a $\beta_{2} \mathrm{M}$ focused survey in the field of oncology). Nevertheless, the function of FcRn merits special mention as it provides a mechanistic link between $\beta_{2} \mathrm{M}$ and another biomarker of special importance to nephrology, i.e., albumin.

\section{The FcRn-A $\beta_{2} M-D e p e n d e n t$ Non-Classical MHC I Molecule That Rescues Serum Proteins from Degradation}

The discovery of the FcRn solved simultaneously two biological puzzles: the maternal transfer of antibodies to the offspring to protect from infections in early life and the persistence of serum albumin and immunoglobulins in the circulation (37, 41,42 ). Studies in the early 1950s and 1960s demonstrated that maternal-fetal transfer of protective antibodies was dependent on the constant $(\mathrm{Fc})$ part of the antibody. Furthermore, the same investigations showed that the same region underlines the long half-life of immunoglobulins vs. other proteins ( $\sim 20$ vs. $\sim 5$ days). The intestinal receptor responsible for transfer of antibodies from the mother's milk to the placenta was cloned as the protein known today as FcRn $(43,44)$. It was subsequently shown that the same protein mediated the long half-life of immunoglobulin G (IgG) in the systemic circulation (45). Albumin also exhibits a long half-life similar to immunoglobulins, and the existence of a protection receptor had long been postulated. It was hypothesized that a similar mechanism to that of the IgG rescue underlined the protection of albumin; this hypothesis-driven research led to the identification of the FcRn as the protein that also protects circulating albumin from degradation (38).

In contrast to the classical MHC-I molecules, the FcRn lacks sequence diversity and cannot present antigens. Nevertheless, it plays an important role in mucosal and systemic sites by rescuing immunoglobulins and albumin from degradation through the transepithelial pathway (transcytosis). $\beta_{2} \mathrm{M}$ interacts with the heavy chain of the FcRn and is important for its proper function $(44,46)$, since mice deficient in $\beta_{2} \mathrm{M}$ demonstrate abnormally short half-lives of $\operatorname{IgG}(47)$ and sequestration of the FcRn in the endoplasmic reticulum (48). Structural and biochemical data [reviewed extensively here $(37,41,42)$ ] suggest that the FcRn will bind simultaneously to albumin and IgG, but at different stoichiometries: a single albumin molecule per FcRn, whereas a single IgG will simultaneously bind to two FcRn molecules. The whole body kinetics of albumin and IgG rescue by the FcRn have been studied and a simplified model developed and fit to experimental data (49). This model makes several predictions: (1) almost one third of FcRn are available for albumin recycling, (2) the maximal capacity of albumin rescue is double that of $\operatorname{IgG}$, (3) the molar recycling rate of albumin is three times that of $\operatorname{IgG}$, and (4) two thirds of the plasma concentration of albumin are maintained by production rather than recycling.

More recent findings [reviewed in Ref. $(37,41)$ ] suggest a more expanded role of the FcRn as an integral part of immune defense, bidirectionally transporting immunoglobulins and antigens to the mucosal immune system. Professional antigen-presenting cells take up antigen-IgG complexes through the classical Fc receptor $(\mathrm{Fc} \gamma \mathrm{R})$ at neutral $\mathrm{pH}$, thus initiating receptor-mediated endocytosis. Acidification of phagolysosomes leads to "hand-off" between the FcyR and the FcRn and the delivery of the antigen to pathways that eventually load the antigen onto MHC-I and MHC-II molecules. The end result is a potent elicitation of $\mathrm{CD}^{+}$ and $\mathrm{CD}^{+}$responses against bacterial and viral antigens $(37,41)$.

\section{The Role of the FcRn in the Kidney}

The FcRn is also expressed in the kidney, where it facilitates clearance of both immunoglobulins $(50,51)$ and albumin (52). There is some evidence for differential handling of albumin (reclamation back into the circulation) vs. immunoglobulins (elimination into the urine) $(50,53)$ by the intrarenal FcRn system. The role of the FcRn in renal physiology (albumin handling) and renal disease has been explored in numerous publications involving genetic knockouts and pharmacological interventions. This was shown in experiments in which wild type were transplanted to FcRn-knockout mice and vice versa. Transplantation of wildtype kidney to FcRn knockout mice resulted in amelioration of albuminuria and restoration of normal urinary IgG levels. This differential handling not only prevents accumulation of protein complexes that could potentially interfere with glomerular filtration, but also provides immune protection in the urinary tract. Importantly, impaired clearance of immunoglobulins by knocking out the FcRn did not result in accumulation of IgG in the glomerular basement membrane, but rendered such animals more susceptible to nephrotoxic insults (50). There is some evidence 
that the podocyte FcRn system functions as an immune sensor that triggers the inflammatory response seen in certain glomerulonephritides. In particular, antithymocyte globulin treatment of podocytes increases the expression of FcRn from its high baseline state, leading to phosphorylation of the p38 mitogen-activated protein kinase, p38MAPK (54). In the same study, the percentage of glomeruli with at least two podocytes staining positive for the FcRn was characterized in human biopsies. The expression percentage was significantly higher in immune-mediated disease, including membranous nephropathy (46.7\%), IgA nephropathy (66.7\%), lupus nephritis (87.5\%), and acute proliferative glomerulonephritis (100\%), than in normal kidney samples $(16.7 \%)$ $(P<0.05)$, whereas there was no significant difference between minimal-change disease and normal kidney. The relation between FcRn and p38MAPK signaling may be of pathogenetic significance since p38MAPK appears to be a major profibrotic pathway in diabetic (55), experimental nephrotic syndrome (56), and hypertensive kidney disease (57), whose inhibition leads to reduced blood pressure, sclerosis, podocyte injury, and apoptosis (58). In particular, one may postulate that activation of the $\beta_{2} \mathrm{M}$ containing FcRn (e.g., by proteinuria) may trigger pathways of fibrosis inside the kidney through the p38MAPK pathway. This hypothesis, which needs to be verified experimentally, may underline the pathogenetic role of proteinuria in accelerating kidney disease progression to dialysis-dependent ESRD (59).

A major hypothesis in the nephrology literature is that proteinuria (albuminuria) underlines the progression of diverse forms of kidney disease $(59,60)$ and that the renoprotective effects of inhibitors of the renin-angiotensin system are partly mediated through their antiproteinuric effect (60-62). In this schema, increased oxidative stress through the NADPH oxidase system has been seen as a major contributor in promoting the progression of kidney disease (63-65), while antioxidant therapies have been proposed as a therapeutic intervention in $\operatorname{CKD}(66,67)$. Interestingly, albumin overload itself has been shown to activate the reninangiotensin system through oxidase stress and the NADPH pathway (68). These observations raise the possibility that FcRnmediated albumin absorption may be a novel mechanism linking oxidative stress, activation of the renin-angiotensin system, and progression of kidney disease. This underexplored hypothesis has received some support in the literature. In particular, treatment with apocynin, an inhibitor of NADPH oxidase, reduced uptake of albumin by the FcRn and proteinuria in the puromycin model of nephrotic syndrome and proteinuric progressive kidney disease (69). Treatment with a monoclonal antibody against the FcRn reduced proteinuria in the same study. The possibility that the beneficial effects of renin-angiotensin inhibition are mediated to some degree through the FcRn has also been investigated in the literature. In particular, treatment of a mice anti-GBM model of glomerulonephritis with the direct renin inhibitor Aliskeren (70) reduced the glomerular deposition of IgG and reduced proteinuria in parallel with elevations in circulating IgG levels. In fact, animals that do not harbor the FcRn do not develop proteinuria and have reduced deposition of IgG compared to wild-type animals when anti-GBM nephritis is induced. The same data provided suggestive evidence that $\mathrm{FcRn}$ promotes the formation of subepithelial immune complex deposits (71). Finally, treatment of podocytes with IgG derived from patients with lupus, entered the cytoplasm through the FcRn to upregulate the calcium/ calmodulin-dependent protein kinase IV to activate genes linked to podocyte damage and $\mathrm{T}$ cell activation (72). Overall, these data suggest a role for the FcRn- $\beta_{2} \mathrm{M}$ complex in both normal renal handling of albumin [along with the megalin/cubilin albumin receptor (73-75)] and IgG, as an initiating event in the podocyte injury observed in many immunologically mediated renal diseases, but also the oxidative stress that appears to underlie the progression of proteinuric forms of CKD.

\section{Genetic Disorders of $\beta_{2} M$ Function}

Specific mutations that interfere with the binding of $\beta_{2} \mathrm{M}$ to its targets have been described in a number of conditions ranging from the rare familial hypercatabolic hypoproteinemia (immunodeficiency 43) (76-79) to the common genetic hemochromatosis $(80,81)$. The first two patients (siblings from a first cousin marriage) known to suffer from immunodeficiency 43 manifested a complex phenotype of hypoalbuminemia, hypogammaglobulinemia, skeletal abnormalities, and impaired delayed type hypersensitivity skin responses. These patients had circulating and total body pools of IgG less than $28 \%$ of the normal, despite having normal synthetic rates of immunoglobulins. The serum concentration for soluble HLA was less than $0.2 \%$ of normal, and iron indices were all within normal limits (79). The molecular defect was attributed to a single nucleotide trans version (G913C) in the first exon of $\beta_{2} \mathrm{M}$ which impairs the function of FcRn, resulting in hypercatabolism of albumin and immunoglobulins. The immunological phenotype of $\beta_{2} \mathrm{M}$ was investigated in a different consanguineous family, harboring a different homozygous splice site mutation in the first intron of the $\beta_{2} \mathrm{M}$ gene (78). This mutation uncovered a cryptic splice site 4 nucleotides downstream of the canonical one, leading to a frameshift and premature termination of the $\beta_{2} \mathrm{M}$ mRNA. The truncated protein had an extremely short half-life and patients had undetectable circulating and lymphocyte cell-surface $\beta_{2} \mathrm{M}$ levels. HLA-I surface expression was undetectable, but there was intracellular accumulation of the HLA-A heavy chains. As anticipated, patients exhibited absence of all non-traditional MHC I molecules, i.e., CD1a, CD1b, CD1c, and FcRn from the surface of the monocytes. Similar to the first report, affected family members had severe hypoalbuminemia and hypogammaglobulinemia, with normal IgM and IgA levels. IgG responses to viral antigens were maintained, and the response to the antipneumococcal polysaccharide was only slightly reduced. The clinical phenotype was one of the recurrent respiratory tract infections with bronchiectasis, granulomatous dermatitis, and skin ulceration. None of the affected patients ever manifested proteinuria, possibly due to the extremely low levels of serum albumin. Circulating numbers of $\mathrm{CD}^{+}$cells were normal, but this T cell compartment consisted entirely of the $\gamma \delta$ cells. Skin lesions were infiltrated by these T cells, autoreactive NK cells, and perforin-producing $\mathrm{CD} 27^{-} \mathrm{CD} 28^{-} \mathrm{CD} 4$ cells similar to those seen in granulomatosis with polyangiitis. The NK compartment was functionally inactivated and this prevented the development of severe autoimmune phenomena against MHC-I-deficient “missing-self" cells $(78,82)$. 
$\beta_{2} \mathrm{M}$ knockout mice recapitulate many aspects of the human disease (83) and provide a model for the effects of a severe disruption in $\beta_{2} \mathrm{M}$ binding. Such mice exhibit a wide variety of immunological aberrations including suboptimal IgG responses to antigenic stimulation (84), a higher catabolic rate of IgG (47) and albumin (85), hepatic and splenic iron overload (86-89), impaired interferon gamma (IFN- $\gamma$ ), and other cytokine responses (90-92), higher susceptibility to parasitic (93), mycobacterial $(94,95)$, certain viral $(90,96)$ and gram $(-)$ infections $(97,98)$ as well as a higher susceptibility to virus induced tumors $(99,100)$. This animal model has also provided controlled evidence about the rescue role of $\beta_{2} \mathrm{M}$ upon serum albumin, an effect that is mediated through the FcRn $(38,85)$. Interestingly enough these animals do not manifest albuminuria $(101,102)$, a feature that is attributed to the low circulating levels of albumin in these animals or possibly the "leaky" phenotype of $\beta_{2} \mathrm{M}$ knockout mice. Furthermore, $\beta_{2} \mathrm{M}$-deficient mice are in general resistant to the development of proteinuria and renal disease $(101,102)$. When $\beta_{2} \mathrm{M}$ is knocked out in the MRL-fas ${ }^{l p r}$ spontaneous lupuslike model, renal (but not skin) disease is inhibited $(103,104)$. Nevertheless, renal disease with the massive deposition of intrarenal immune complexes may be induced in such animals after specific and intense immunization protocols (105).

The association between $\beta_{2} \mathrm{M}$ deficiency and iron overload is worthy of special mention, because it recapitulates some aspects of hereditary hemochromatosis. In the most common form of the latter disease, a C260Y mutation in the HFE molecule disrupts its association with $\beta_{2} \mathrm{M}$ leading to systemic iron overload. The genetics and the clinical manifestations of hemochromatosis are very complex (106), but iron overload is seen irrespective of whether the genetic lesion refers to HFE or $\beta_{2} \mathrm{M}$. Nevertheless, there are important biochemical differences, since $\beta_{2} \mathrm{M}$-deficient mice have higher hepcidin levels which correlate inversely with the severity of hepatic iron overload (88). Furthermore, these animals fail to respond to iron overload by upregulating hepcidin levels. This may be due to abnormal cellular localization of hepcidin as seen in $\beta_{2} \mathrm{M}$ silencing RNA knockdown experiments (107).

\section{WHOLE BODY METABOLISM AND BIOMARKER KINETIC MODEL OF $\beta_{2} M$}

Beta-2 microglobulin is continuously generated by all nucleated cells of the body. The plasma level of $\beta_{2} \mathrm{M}$ is thought to reflect release of molecules that are non-covalently bound to MHC-I into the circulation and once in the plasma $\beta_{2} \mathrm{M}$ is freely filtered by the glomerulus (108). $\beta_{2} \mathrm{M}$ is easily and accurately measurable with most of the commercial laboratories using the highly sensitive nephelometry method $(109,110)$. Serum $\beta_{2}$ M levels are not necessarily independent of sex, race, and ethnicity (111-113). However, in all studies to date it was found that elderly have higher serum $\beta_{2} \mathrm{M}$ levels. As we will see later on in this review serum $\beta_{2} \mathrm{M}$ levels also increase in solid organ malignancies, lymphoproliferative disorders such as myeloma and chronic lymphoblastic leukemia, and many autoimmune diseases such as Crohn's disease, Sjögren's syndrome, systemic lupus erythematosus, and rheumatoid arthritis. All these are conditions, under which one would expect a higher number of cells bearing $\mathrm{MHC}$ molecules to be generated, or conditions in which higher shedding of $\beta_{2} \mathrm{M}$ is observed (114-116).

The multiple influences affecting both generation and elimination of $\beta_{2} \mathrm{M}$ raise the need for a quantitative understanding of the factors of generation, elimination, and body compartment distribution affecting the biomarker's concentrations. Our group produced such a population-level model by performing a kineticbased meta-analysis of the existing studies in the field over the last 40 years (117). According to this model (Figure 2), $\beta_{2} \mathrm{M}$ obeys bicompartmental kinetics and thus its behavior is a highly nonlinear function of the relevant kinetic parameters. This is especially true in patients receiving hemodialysis (HD), who experience interdialytic (fluid ingestion) and intradialytic (ultrafiltration) compartment volume changes. The model may also be applied to study the kinetics of $\beta_{2} \mathrm{M}$ in non-dialysis patients. In this case, considerable simplification is afforded by the lack of inter- and intradialytic volume changes and the discontinuous nature of dialytic clearance. A steady-state solution may in fact be recovered by solving the relevant bicompartmental system. However, this formula is too complex for practical use. This model, which is largely based on investigations in mostly Caucasian, youngmiddle-aged adult patients receiving $\mathrm{HD}$, recapitulates many important clinical observations in both CKD and ESRD. The average serum $\beta_{2} \mathrm{M}$ concentration in the "simulated" population was $1.59 \pm 0.64 \mathrm{mg} / \mathrm{l}$, while only $3.5 \%$ of simulated values were outside the upper reference range of $3 \mathrm{mg} / \mathrm{l}$ quoted in laboratory medicine references (118). This average compares favorably with the values previously reported to be: $1.53 \mathrm{mg} / \mathrm{l}$ (113), $1.62-1.86$ (range of individuals with age compatible with the range in our kinetic meta-analysis) $\mathrm{mg} / \mathrm{l}(112)$, and $1.9 \pm 0.4 \mathrm{mg} / \mathrm{l}$ (119). Due to its derivation from first principles, this population kinetic biomarker model may also allow a more rigorous, quantitative evaluation of other factors (e.g., generation) affecting serum $\beta_{2} \mathrm{M}$ concentration. This is a perspective that we explore in the conclusion of this review.

\section{USING $\beta_{2} M$ TO ASSESS GLOMERULAR FUNCTION}

There are various ways to assess renal function with changes in glomerular filtration rate (GFR) being the most widely used method. This is achieved by assessing the plasma or the urinary clearance of filtration markers with an ideal endogenous marker being the one that appears at a constant rate in plasma, is freely filtered by the glomerulus, is neither absorbed into the circulation nor secreted by the tubules, and it is not removed from extrarenal sites. Estimation of GFR by Cr-based equations lacks precision and accuracy due to non-renal determinants-such as non-renal removal, renal secretion, and variations in muscle mass-affecting serum Cr level. Researchers have been in constant search of an ideal filtration marker. In this section, we will review the evidence arguing for the adoption of $\beta_{2} \mathrm{M}$ as an additional marker of glomerular filtration in CKD. 


\section{Role of $\beta_{2} \mathrm{M}$ for the Assessment of GFR in Adults}

Numerous studies to date have demonstrated large correlations between measures of renal function and suitably transformed serum levels of $\beta_{2} \mathrm{M}$ (Table $\mathbf{1}$ ). These studies provide compelling reasons to suspect that one can estimate renal filtration with a $\beta_{2} \mathrm{M}$ estimating equation. Recent research has explored the advance, if any, of such equations over the Cr-based estimated GFR (eGFR).

The Chronic Kidney Disease Epidemiology Collaboration (CKD-EPI) group developed a $\beta_{2} \mathrm{M}$-based GFR estimating equation in a cohort of 2,380 patients primarily comprised of Caucasians and African Americans with a mean measured GFR (mGFR), serum Cr, and serum $\beta_{2}$ M levels of $47.5( \pm 21.7)$ $\mathrm{ml} / \mathrm{min} / 1.73 \mathrm{~m}^{2}, 1.9( \pm 0.9) \mathrm{mg} / \mathrm{dl}$, and $4.3( \pm 2.4) \mathrm{mg} / \mathrm{l}$, respectively (39). $\beta_{2} \mathrm{M}$ was strongly positively correlated with serum cystatin $\mathrm{C}$ and $\mathrm{Cr}$ with Pearson coefficients of 0.9 and 0.78 , respectively. Serum $\beta_{2} \mathrm{M}$ was negatively correlated with GFR with a Pearson coefficient of -0.85 . The authors included the variables of age, sex, and race in the least error regression model for equation development-the coefficients for $\beta_{2} \mathrm{M}$ were significant albeit small, similar to those of cystatin $\mathrm{C}$, and smaller than those for $\mathrm{Cr}$. Addition of these variables did not substantially improve equation performance in the whole cohort as well as various subgroups, therefore, the final equation did not include these variables. This report also compared the precision and accuracy of equations using the metrics of interquartile range of error (difference between mGFR and eGFR of each subject), proportion of the patients in whom the eGFR was not within $30 \%$ $\left(1-P_{30}\right)$ and $20 \%\left(1-P_{20}\right)$ of $\mathrm{mGFR}$ and root mean square error, respectively (Table 2 ). In that cohort, the CKD-EPI $\beta_{2} \mathrm{M}$ equation achieved comparable accuracy to the CKD-EPI Cr, cystatin C, and the $\mathrm{Cr}$-cystatin $\mathrm{C}$ equation. Nevertheless, the CKD-EPI $\beta_{2} \mathrm{M}$ has an advantage over the other CKD-EPI equations in that it is independent of race, age, and sex.

Since the $\beta_{2} \mathrm{M}$ estimating equation was not strongly correlated with age, sex, and race, the authors concluded that there are some other non-renal determinants of serum $\beta_{2} \mathrm{M}$ and addition of those factors-if readily measurable-will lead to improvement in equation performance. One should note the apparent discrepancy between the lack of correction factors for age, gender, and race in the estimating equation for $\beta_{2} \mathrm{M}$ and previously reported associations between these factors and the serum level of $\beta_{2} \mathrm{M}(111,112,133)$. In multivariate adjusted models (133), only race (lower in blacks), smoking (higher in smokers), and proteinuria (higher in patients with proteinuria) retained intermediated associations with a higher serum $\beta_{2} \mathrm{M}$ concentration. This discrepancy should be taken as evidence of the $\beta_{2} \mathrm{M}$ to be a

TABLE 1 | Relationship between beta-2 microglobulin $\left(\beta_{2} M\right)$ and glomerular filtration rate (GFR) in adults.

\begin{tabular}{|c|c|c|c|c|}
\hline Study & GFR measure & Correlation $\left(1 / \beta_{2} M\right)$ & Correlation $\left(\beta_{2} \mathrm{M}\right)$ & Slope linear regression \\
\hline Vincent et al. (120) & Inulin clearance & - & - & -0.87 \\
\hline Wibell et al. (121) & Inulin clearance & - & -0.94 & -0.89 \\
\hline Swanson et al. (113) & lothalamate clearance & - & - & -0.82 \\
\hline Shea et al. (122) & lothalamate clearance & 0.90 & - & - \\
\hline Inker et al. (123) & lothalamate clearance & - & - & -0.85 \\
\hline Aparicio et al. $(124)^{\mathrm{b}}$ & ${ }^{51} \mathrm{Cr}-\mathrm{EDTA}$ & 0.79 & - & -0.75 \\
\hline Grubb et al. (20) & ${ }^{51} \mathrm{Cr}$-EDTA & 0.59 & - & - \\
\hline Yun et al. $(125)^{c}$ & 24-h creatinine clearance & - & - & -0.79 \\
\hline Jovanović et al. (126) & 24-h creatinine clearance & 0.80 & - & - \\
\hline Shea et al. (122) & 24-h creatinine clearance & 0.87 & - & - \\
\hline Aksun et al. (127) & 99mTC-DTPA GFR & - & -0.48 & - \\
\hline Bianchi et al. (128) & ${ }^{99 m}$ TC-DTPA GFR & 0.76 & - & -0.81 \\
\hline Donadio et al. (129) & 99mTc-DTPA GFR & 0.73 & - & - \\
\hline Donadio et al. (130) & 99mTc-DTPA GFR & - & - & -0.81 \\
\hline Fry et al. $(131)^{d}$ & Timed urea collections & - & -0.63 & - \\
\hline Vilar et al. (132)d & Average of urea and creatinine collections & 0.82 & -0.72 & - \\
\hline
\end{tabular}

The table reports the slope of the linear regression between log concentration and log clearance.

- Not reported.

aStudied patients with type 2 diabetes.

${ }^{b}$ Studied patients with sickle cell disease.

'Studied patients with multiple myeloma.

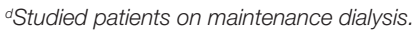

TABLE 2 | Performance of beta-2 microglobulin $\left(\beta_{2} \mathrm{M}\right)$, creatinine (Cr), and/or cystatin C-derived equations.

\begin{tabular}{|c|c|c|c|c|}
\hline Equation & Interquartile range $(95 \% \mathrm{Cl})$ & $1-P_{30}(\%)(95 \% \mathrm{Cl})$ & $1-P_{20}(\%)(95 \% \mathrm{Cl})$ & Root mean square error $(95 \% \mathrm{Cl})$ \\
\hline Chronic kidney disease (CKD)-EPI $\beta_{2} \mathrm{M}$ & $12.9(12.2-13.8)$ & $18.4(16.2-20.8)$ & $37.2(34.6-40.1)$ & $0.24(0.231-0.257)$ \\
\hline CKD-EPI Cr & $11.6(10.9-12.4)$ & $16.4(14.2-18.6)$ & $34.5(31.7-37.3)$ & $0.224(0.213-0.236)$ \\
\hline CKD-EPI Cys & $11.4(10.6-12.4)$ & $16.9(14.9-18.6)$ & $34.8(32.1-37.6)$ & $0.228(0.217-0.239)$ \\
\hline CKD-EPI Cr-Cys & $9.3(8.7-10.1)$ & $11.3(9.5-13.2)$ & $25.5(23.1-28.0)$ & $0.189(0.180-0.199)$ \\
\hline
\end{tabular}


somewhat superior marker of renal filtration that has higher correlations to the measured GFR and smaller correlations to these non-renal determinants than Cr per se $(123,133)$. Nevertheless, the influences of non-renal determinants on other factors affecting $\beta_{2} \mathrm{M}$ kinetics (e.g., generation) nullify this putative advantage, so that the overall performance of CKD-EPI $\beta_{2} \mathrm{M}$ equation is not different from that of other estimating equations.

To gain a better understanding of the performance of the CKD-EPI equation (134):

$$
\mathrm{eGFR}_{\beta_{2} \mathrm{M}}=133 \times \beta_{2} \mathrm{M}^{-0.854}
$$

we compared it to simulations based on our meta-analysis of the kinetic studies (117). These simulations, which were repeated for various levels of renal function, were then summarized with descriptive statistics (Figure 3), e.g., the mean (red), median (blue), and 95\% quantile range (gray band). The relationship predicted by the CKD-EPI $\beta_{2} \mathrm{M}$ equation (Figure 3, black) is essentially identical to the one predicted by the kinetic model, until about $40 \mathrm{ml} / \mathrm{min}$. Below this level of GFR, the estimating equation predicts lower clearances for the same serum level of $\beta_{2} \mathrm{M}$. We can explain this divergence by considering that (a) a major underlying assumption of the kinetic model is that generation of $\beta_{2} \mathrm{M}$ is not affected by renal impairment and (b) the nonrenal determinants (e.g., variable generation) of serum $\beta_{2} \mathrm{M}$ have been embedded into the coefficients of the estimating equation. It is worth remembering that the latter equation predicts an average relation that was estimated in cohorts with renal impairment and

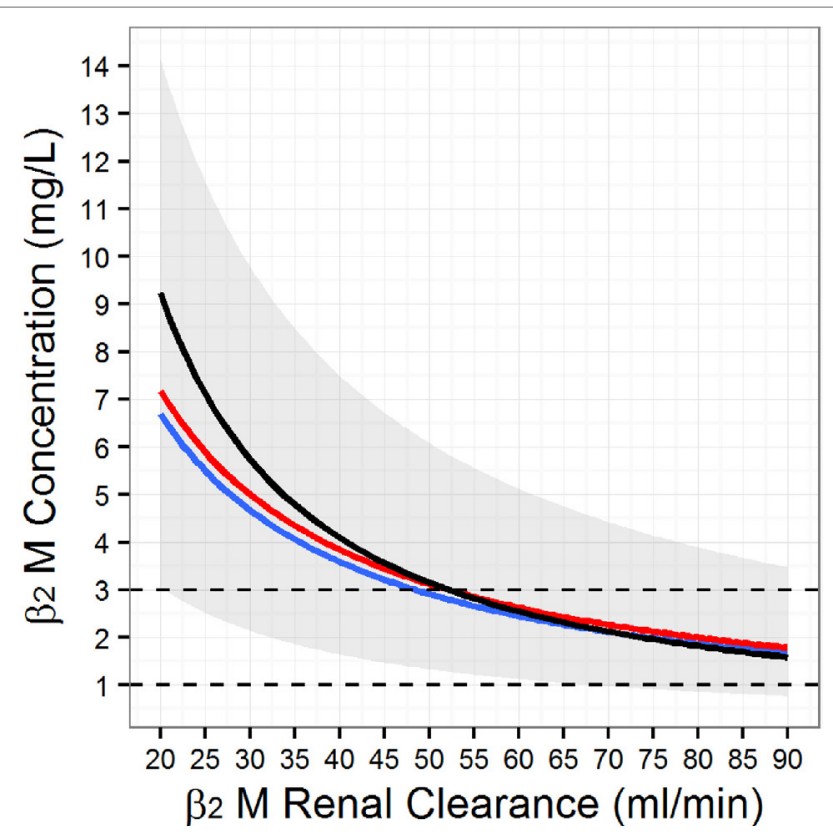

FIGURE 3 | Simulated serum beta-2 microglobulin $\left(\beta_{2} M\right)$ as a function of the glomerular filtration rate. To generate the figure we simulated 10,000 individuals from the population model for $\beta_{2} \mathrm{M}$ kinetics (117) at different levels of renal function. At each level of renal function, we computed the mean (red line), the median (blue line), and the associated population 95\% range (gray band). Finally, we superimposed the Chronic Kidney Disease Epidemiology Collaboration $\beta_{2} \mathrm{M}$ estimating equation (black line). an average $\mathrm{mGFR}$ of $47.7 \mathrm{ml} / \mathrm{min} / 1.73 \mathrm{~m}^{2}$. If the generation rate of $\beta_{2} \mathrm{M}$ varies at different levels of glomerular filtration, we would expect the statistical procedure used by the CKD-EPI investigators to balance out the influences of generation and elimination during model fitting. Furthermore, if generation is higher at lower levels of mGFR, then one would expect the CKD-EPI to provide a steeper curve between $\beta_{2} \mathrm{M}$ and renal clearance than the true relation (as provided by the kinetic model) at both lower (Figure 3) and higher serum $\beta_{2} \mathrm{M}$ levels. With respect to the latter point, the CKD-EPI investigators also reported that this equation underestimates mGFR at higher levels of renal function. Taken together, these observations reinforce the argument of the CKDEPI group that poorly understood factors other than the age, sex, and race affect serum $\beta_{2} \mathrm{M}$ levels. Even though the kinetic model does not allow us to pinpoint the nature of these factors, it can at least proportionate the influences of the generation and elimination processes. This feature may allow one to explore various "what-if-else" scenarios when designing clinical studies to further develop $\beta_{2} \mathrm{M}$ as a biomarker.

\section{Role of $\beta_{2} \mathrm{M}$ for the Assessment of GFR in Pediatric Populations}

Creatinine clearance is known to be an unreliable marker for the measurement of GFR in children due to the changing muscle mass with age. Hence other markers, including serum $\beta_{2} \mathrm{M}$, which is not influenced by muscle mass, have been investigated as potential markers that may more accurately estimate GFR. Studies published have shown mixed results. Some studies concluded that serum $\beta_{2} \mathrm{M}$ may be a reliable marker to predict GFR (135-137), while others have not $(138,139)$. Furthermore, the recently developed CKD-Epi-Beta Trace- $\beta_{2} \mathrm{M}$ formula (123) cannot be applied in children (140). In summary, the use of serum $\beta_{2} \mathrm{M}$ as a measure of glomerular filtration function does not appear to be as useful in children relative to adults. However, the urinary $\beta_{2} \mathrm{M}$ excretion has been used in the diagnosis of a wide variety of renal diseases in children as we discuss in the subsequent section.

\section{URINARY $\beta_{2} M$ FOR THE ASSESSMENT OF TUBULAR FUNCTION}

The removal of $\beta_{2} \mathrm{M}$ from the serum is primarily by glomerular filtration but more than $99.9 \%$ of the filtered protein is reabsorbed and catabolized in the proximal convoluted tubule resulting in minimal urine concentration of $\beta_{2} \mathrm{M}$ (usually less than $360 \mu \mathrm{g} / \mathrm{l}$ ) $(141,142)$. The removal of $\beta_{2} \mathrm{M}$ from the tubular fluid is postulated to be mediated through the megalin-cubilin complex $(143,144)$, on the basis of ligand blotting assays (145), megalin animal knockouts (146), and the human disease Donnai-Barrow/ Facio-Ocular-Acoustico-Renal Syndrome (OMIM \#222448) (147). This syndrome is associated with multisystemic abnormalities, developmental delay, and tubular proteinuria as a result of mutations in the LRP2 megalin gene (148). This interaction may be mediated by the megalin component of the megalincubilin complex, since human cubilin mutations (megaloblastic anemia 1, OMIM \#261100) manifest tubular proteinuria but with normal urinary $\beta_{2} \mathrm{M}$ levels (149). 
Proteins endocytosed through the megalin/cubilin complex are targeted to the endosomes, where ligands are released from their receptors through acidification $(143,150)$. It is not known how much of $\beta_{2} \mathrm{M}$ is degraded within the lysosomes, recycled with other MHC to the membrane surface, or transported to the basolateral surface (such as thyroglobulin or retinol binding protein). Data from experiments in rats provide evidence that $\beta_{2} \mathrm{M}$ is targeted to the lysosomes (151), so that degradation appears to be the most likely fate for $\beta_{2} \mathrm{M}$. However, there is also conflicting evidence for convergent apical and basolateral endocytic systems in the proximal tubule $(151,152)$. As human proximal epithelial cells are capable of transcytosis of the FcRn- $\beta_{2}$ M-IgG (153), it is possible that some of the reabsorbed urinary $\beta_{2} \mathrm{M}$ is transcytosed. However, to our knowledge no study has specifically looked for transcytosis of $\beta_{2} \mathrm{M}$ absorbed through the megalin pathway. Experiments reported four decades ago provide some evidence for competitive inhibition for the absorptive tubular mechanism between $\beta_{2} \mathrm{M}$ and other proteins in the tubular fluid (154-157). More recent experiments suggest similar transport kinetics arguing for a single mechanism mediating this process (158). Hence, one could anticipate variable urinary excretion levels of $\beta_{2} \mathrm{M}$ in the presence of glomerular proteinuria. The tubular handling of $\beta_{2} \mathrm{M}$ exhibits maturation during the neonatal period. The urinary $\beta_{2} \mathrm{M}$ excretion peaks by the fifth day of life and gradually declines to adult level by 3 months of age (159). This feature suggests that urinary $\beta_{2} \mathrm{M}$ not only may be a reliable biomarker of tubular toxicity but also it may even have an age dependent performance.

\section{Role of $\beta_{2} M$ for the Assessment of Tubular Function in Adults}

Since its initial discovery from the urine of humans with cadmium toxicity, $\beta_{2} \mathrm{M}$ has been used to assess tubular function. More recently, the Nephrotoxicity Working Group of the Critical Path Institute Predictive Safety Testing Consortium assessed urinary $\beta_{2} \mathrm{M}$, along with other three biomarkers of nephrotoxicity (urinary clusterin, urinary cystatin $\mathrm{C}$, and urinary total protein) in 10 mechanistic time-course studies involving 739 rats treated with eight nephrotoxins known to induce different types of renal lesions and two hepatotoxins as a means to assess specificity for kidney vs. other organ toxicity (160). Of note, $\beta_{2} \mathrm{M}$ and cystatin $\mathrm{C}$ were specific for glomerular alternations, and with the exception of the gentamicin model, no systematic increase of either protein in urine or kidney tissue could be demonstrated when rats were exposed to other tubular toxins. Another recent animal toxicology study evaluated the performance of neutrophil gelatinase-associated lipocalin (NGAL) and four urinary biomarkers deemed acceptable by the regulatory authorities to detect acute drug-induced renal toxicity (161): $\beta_{2} \mathrm{M}$, cystatin C, kidney injury molecule-1 (KIM-1), and clusterin. In this particular study, urinary $\beta_{2} \mathrm{M}$ and cystatin $\mathrm{C}$ increased early (prior to the detection of histological changes) and returned to the control range in the recovery phase. Furthermore, plasma $\beta_{2} \mathrm{M}$ changes paralleled changes in urinary $\beta_{2} \mathrm{M}$, but correlations between the biomarker values varied according to the nephrotoxin. Nevertheless, a more extensive evaluation of 12 markers for sensitivity (renal toxicity) and specificity (non-renal organ toxicity) in 22 rat studies, reveal that $\beta_{2} \mathrm{M}$ (and cystatin $\mathrm{C}$ ) had relatively poor area under the curve (AUC) for both tubular $(\mathrm{AUC}=0.72)$ and glomerular (AUC $=0.85$ ) toxicities (162). In the same study, urinary albumin had one of the best performance for both tubular (AUC $=0.90 \mathrm{vs}$. $\mathrm{AUC}=0.96$ of the best performing KIM-1) and glomerular (AUC $=0.99$, best performing) toxicity. Collectively, the recent animal toxicology data raise important questions about both the specificity of urinary $\beta_{2} \mathrm{M}$ for tubular lesions, i.e., this compound appears to detect glomerular injury better than tubular damage, and its overall utility relative to the more easily obtained assay for albuminuria. Interestingly, significant correlations between urinary $\beta_{2} \mathrm{M}$ and other indices of renal damage (e.g., protein/Cr ratio) have been reported in IgA nephropathy (163) and systemic lupus erythematosus (164). Both these conditions are characterized by predominantly glomerular lesions. Consequently, controlled toxicological data and observational reports suggest some caution when interpreting urinary $\beta_{2} \mathrm{M}$ elevations as indicative of a bona fide tubular process. In particular, one should always entertain the hypothesis of a glomerular process leading to proteinuria and competition of the filtered protein load for the reabsorption process in the proximal tubule (156) when interpreting a high urinary $\beta_{2} \mathrm{M}$ level. Needless to say, there are virtually no human data about specific diagnostic cutoffs of the urinary $\beta_{2} \mathrm{M}$; even the three aforementioned toxicological rat studies provide different cutoff values.

A meta-analysis of various urinary biomarkers has confirmed that the value of urinary $\beta_{2} \mathrm{M}$ may be limited in clinical acute kidney injury (AKI) due to sepsis (165). In this meta-analysis urinary $\beta_{2} \mathrm{M}$ was found to be associated with changes in serum $\mathrm{Cr}$ and could differentiate between prerenal azotemia and tubular necrosis, but could not predict the clinically important outcome of need for renal replacement therapy. More recently, Zeng et al. conducted a study of diagnostic accuracy in 47 patients (166). The reference test was urinary $\beta_{2} \mathrm{M}$ (normal urinary $\beta_{2} \mathrm{M}$ range: $230-300 \mu \mathrm{g} / \mathrm{l})$. The sensitivity and specificity of urinary $\beta_{2} \mathrm{M}$ in detecting tubular injury (assessed through KIM-1 staining in renal biopsies) was $86.6 \%$ and $64.7 \%$, respectively. In summary, there is currently very limited evidence about the utility of urinary $\beta_{2} \mathrm{M}$ in the diagnosis of $\mathrm{AKI}$; most of the data come from the era of high-dose aminoglycoside therapy. Under these conditions, release of $\beta_{2} \mathrm{M}$ in the urine may not even reflect actual toxicity (167). Important limitations of the literature to date are poor standardization of urine collection protocols for $\beta_{2} \mathrm{M}$ and the poor stability of the analyte in acidic urine (168-171).

Various population-based studies have shown that urinary $\beta_{2} \mathrm{M}$ levels can be used to detect tubular injury due to various toxins. $\beta_{2} \mathrm{M}$ has been used as a marker of tubular dysfunction in subjects exposed to heavy metals such as cadmium with urinary $\beta_{2} \mathrm{M}$ levels strongly correlating with serum cadmium levels (172-175). Rybakowski et al. showed that lithium-treated patients were more likely to have higher urinary $\beta_{2} \mathrm{M}$ and lower eGFR than patients not treated with lithium (176). Beta-2 microglobinuria was also seen in HIV patients on tenofovir (177-179). 


\section{Role of $\beta_{2} \mathrm{M}$ for the Assessment of Tubular Function in Pediatric Populations \\ Tubulo-Interstitial Diseases}

Urinary excretion of $\beta_{2} \mathrm{M}$ either in the form of fractional excretion of $\beta_{2} \mathrm{M}\left(\mathrm{FE}-\beta_{2} \mathrm{M}\right)$ or 24 -h urine $\beta_{2} \mathrm{M}$ excretion has been used in the diagnosis of tubulo-interstitial diseases (180). This study examined children with glomerular $(N=114)$, tubular $(N=50)$, or other $(N=18)$ renal diseases and showed that children with tubulo-interstitial disease had significantly higher FE- $\beta_{2} \mathrm{M}$ (mean $4.27 \%$ ) compared to children with glomerular disease alone $(0.104 \%)$. This difference seen was not due to impairment in GFR alone as at any given eGFR, patients with tubulo-interstitial disease had higher $\mathrm{FE}-\beta_{2} \mathrm{M}$ compared to patients with glomerular disease alone (142). Children with glomerular disease and a high $\mathrm{FE}-\beta_{2} \mathrm{M}$ who underwent a renal biopsy $(N=13)$, were found to have focal areas of fibrosis, plasma cell or lymphocyte infiltration, or tubular atrophy. These patients were found to have poorer prognosis compared to patients who had pure glomerular disease. This finding was later refuted by a subsequent study (181), which showed that the urinary excretion of low-molecular weight protein (LMWP) in children with glomerular disease did not necessarily portend a poor prognosis. Urinary $\beta_{2} \mathrm{M}$ excretion has also been used in the diagnosis of a variety of renal diseases that affect tubulo-interstitial function including tubule-interstitial nephritis with uveitis (182), hemoglobinopathies such as sickle cell disease $(183,184)$, as well as children who have received chemotherapy as part of their cancer treatment (185).

\section{Localization of Urinary Tract Infection (UTI) and Detection of Urinary Obstruction}

As urinary $\beta_{2} \mathrm{M}$ level is an important reflection of tubular function of the kidneys, measuring the urine level has been used in the localization of UTI in children. Studies have shown that children with upper UTI tend to have higher urinary $\beta_{2} \mathrm{M}$ excretion compared to children with lower UTI $(186,187)$ hence allowing for more accurate localization of infection and treatment strategies. Serum and urinary $\beta_{2} \mathrm{M}$ have also been shown to be elevated in children with reflux nephropathy (188).

Urinary NGAL and $\beta_{2} \mathrm{M}$ have been proposed as useful tests for the diagnosis of obstructive uropathy due to ureteropelvic junction obstruction as the levels were elevated in the pre- and peri-operative period and improved with the relief of obstruction (189). However, the control group in this study was comprised of healthy children with no renal impairment, hence it is unclear whether the elevated urinary NGAL and $\beta_{2}$ M level was a reflection of the impaired renal function or the obstruction itself.

\section{Acute Kidney Injury (AKI)}

Creatinine is a poor marker for AKI due to various factors including the influence of muscle mass, fluid status, and/or delayed increase in level after the occurrence of kidney injury making early intervention impossible. $\beta_{2} \mathrm{M}$ has been investigated as a candidate biomarker for AKI as it is muscle mass-independent and the rise in serum $\beta_{2} \mathrm{M}$ levels occurs earlier compared to the rise in serum Cr levels (190). A recent study (191) showed that both serum cystatin $\mathrm{C}$ and $\beta_{2} \mathrm{M}$ were better biomarkers compared to $\mathrm{Cr}$ in the detection of AKI in critically ill children. In a prospective study of 252 children who presented to the emergency department, urinary $\beta_{2} \mathrm{M}, \mathrm{NGAL}$, and KIM-1 demonstrated good accuracy (AUC > 0.7-0.8) in predicting AKI (192). The caveat with using $\beta_{2} \mathrm{M}$ as a biomarker for $\mathrm{AKI}$ is that the level varies with gestational age, hence caution will need to be exercised in using this serum marker in premature infants $(193,194)$.

In summary, measuring serum and urine $\beta_{2} \mathrm{M}$ has been used in both predicting GFR and diagnosing renal diseases in children with variable success. Urinary $\beta_{2} \mathrm{M}$ level has been helpful in the diagnosis and the monitoring of children afflicted by diseases that affect tubular function or in those who have or will be receiving medications that could affect the tubular function. Furthermore, urinary $\beta_{2} \mathrm{M}$ may also be a useful marker for the early detection of AKI. Nevertheless, provocative animal and human data suggest that it may a better marker of glomerular, rather than tubular injury.

\section{$\beta_{2}$ M AS A BIOMARKER OF ADVERSE CLINICAL OUTCOMES AND MORTALITY IN CKD}

There is limited research and evidence examining the role of serum $\beta_{2} \mathrm{M}$ as a biomarker being able to predict adverse outcomes and mortality across the spectrum of predialysis CKD. We identified five recent studies examining the prognostic role of $\beta_{2} \mathrm{M}$ in patients with CKD.

In the first study, the authors examined the relationship of plasma $\beta_{2} \mathrm{M}$ levels to clinical and CV outcomes in 142 patients (mean age 67 years) at different stages of CKD. Plasma $\beta_{2} \mathrm{M}$ levels increased with CKD stage and thus were highest in HD patients (195). Baseline plasma $\beta_{2} \mathrm{M}$ levels were associated with vascular calcification but not with arterial stiffness or bone density. During a mean follow-up of 969 days, 44 patients died and 49 suffered a CV event. Higher plasma $\beta_{2} \mathrm{M}$ levels were independently associated with overall and CV mortality and CV events in the whole cohort and with CV events in the predialysis cohort. Moreover, plasma $\beta_{2} \mathrm{M}$ appeared to be a better predictor than well-established factors associated with outcomes in this population, such as eGFR (only for predialysis patients), inflammation biomarkers, and other factors included in a propensity score. Thus, they confirmed a strong relationship between plasma $\beta_{2} \mathrm{M}$ levels and eGFR and the power of plasma $\beta_{2} \mathrm{M}$ to predict overall and CV mortality and CV events in patients at different stages of CKD.

The association of serum $\beta_{2} \mathrm{M}$ with hard clinical outcomes and its predictive ability was also examined in a prospective cohort study on behalf of the CKD Biomarker Consortium and the Chronic Renal Insufficiency Cohort (CRIC) Study Investigators (196). They examined the potential role of serum $\beta_{2} \mathrm{M}$ as predictor of ESRD, mortality, and new-onset CV disease in 3,613 adults with CKD from the CRIC Study. During a 6-year median followup, 755 (21\%) participants developed ESRD, 653 died, and 292 developed new-onset $\mathrm{CV}$ disease. After multivariable adjustment serum $\beta_{2} \mathrm{M}$ was an independent predictor of ESRD, all-cause 
mortality, and CV events. These associations were stronger than those observed for the Cr-based eGFR $(P \leq 0.02)$.

Furthermore, in 2015 an interesting longitudinal cohort study came out by the same group on behalf of the CKD Biomarkers Consortium (197). They examined incident ESRD and mortality in 250 Pima Indians with type 2 diabetes (DM II) and whether serum $\beta_{2} \mathrm{M}$ was associated with these outcomes. During a median follow-up of 14 years, 69 participants developed ESRD and 95 died. Serum $\beta 2 \mathrm{M}$ was associated with ESRD after adjustment for traditional risk factors and established filtration markers.

Another study examined the associations among serum $\beta_{2} \mathrm{M}$, malnutrition, inflammation, and atherosclerosis (MIA) in 312 patients with CKD between 2009 and 2015 (198). They found that serum $\beta_{2} \mathrm{M}$ was more sensitive than serum $\mathrm{Cr}$ in predicting $\mathrm{CV}$ events and MIA syndrome. This study supports the hypothesis that $\mathrm{CV}$ events in patients with CKD should be understood as part of the MIA complex and that non-renal determinants of serum biomarkers provide prognostic information beyond that afforded by filtration biomarkers or their estimating equations.

Finally, an individual participant data meta-analysis was recently published by the CKD Biomarkers Consortium wherein they examined filtration markers, such as $\beta_{2} \mathrm{M}$, as predictors of ESRD and mortality (199). They included three general population/hazard ratio (GP/HR) studies ( $n=17,903$ participants) and three CKD studies $(n=5,415)$. They compared associations, risk prediction, and improvement in reclassification of eGFR using $\beta$-trace protein (BTP) $\left(e G F R_{\text {BTP }}\right)$ and $\beta_{2} \mathrm{M}\left(\mathrm{eGFR}_{\beta_{2} \mathrm{M}}\right)$ alone and the average $\left(e G F R_{\text {avg }}\right)$ of $e \mathrm{GFR}_{\mathrm{BTP}},\left(\mathrm{eGFR}_{\beta_{2} \mathrm{M}}\right), \mathrm{Cr}\left(\mathrm{eGFR} \mathrm{Cr}_{\mathrm{r}}\right)$, and cystatin $\mathrm{C}\left(\mathrm{eGFR}_{\mathrm{cys}}\right)$, to $e \mathrm{GFR}_{\mathrm{Cr}}, \mathrm{eGFR}_{\text {cys }}$, and their combination (eGFR $\left.\mathrm{er}_{\text {-cys }}\right)$ for ESRD (2,075 events) and death (7,275 events).

Mean (SD) follow-up times for ESRD and mortality for GP/HR and CKD studies were 13 (4), 6.2 (3.2), 14 (5), and 7.5 (3.9) years, respectively. Compared with eGFR $\mathrm{Cr}_{\mathrm{r}}, \mathrm{eGFR}_{\mathrm{BTP}}$ and $\left(\mathrm{eGFR}_{\mathrm{\beta}_{2} \mathrm{M}}\right)$ improved risk associations and modestly improved prediction for ESRD and death even after adjustment for established risk factors. The authors concluded that these markers do not provide substantial additional prognostic information to $\mathrm{eGFR}_{\mathrm{Cr}}$ and albuminuria, but may be appropriate in circumstances where $\mathrm{eGFR}_{\mathrm{Cr}}$ is not accurate or albuminuria is not available.

In 2012, the Atherosclerosis Risk in Communities (ARIC) project investigated novel markers of kidney function as predictors of ESRD, CV disease, and mortality in the general population (200). They included 9,988 participants from population-based study in four US communities, followed for approximately 10 years. They utilized serum Cr-based eGFR calculated using the CKD-EPI equation and serum cystatin C, BTP, and $\beta_{2} \mathrm{M}$ levels. The main outcomes were mortality, coronary heart disease, heart failure, and kidney failure. They found that higher serum cystatin $C$ and $\beta_{2} \mathrm{M}$ concentrations were associated more strongly with mortality $(n=1,425)$ than BTP level and all three biomarkers were associated more strongly with mortality than eGFR $_{\mathrm{Cr}}$ [adjusted HR for the upper 6, 7th percentile compared with the lowest quintile: 1.6 for eGFR $\mathrm{Cr}_{\mathrm{C}}, 2.9$ (95\% CI, 2.3-3.6) for serum cystatin C level, 1.9 (95\% CI, 1.5-2.4) investigators for serum BTP level, and 3.0 (95\% CI, 2.4-3.8) for serum $\beta_{2} \mathrm{M}$ level]. Similar patterns were observed for coronary heart disease $(n=1,279)$, heart failure $(n=803)$, and kidney failure $(n=130)$.
The addition of serum cystatin C, BTP, and $\beta_{2} \mathrm{M}$ levels to models including $\mathrm{eGFR}_{\mathrm{Cr}}$ and all covariates, including urinary albuminCr ratio, significantly improved risk prediction for all outcomes $(P<0.001)$. They concluded that serum $\beta_{2} \mathrm{M}$ and, to a lesser extent, serum BTP levels share cystatin C's advantage over eGFR $\mathrm{Cr}_{\mathrm{r}}$ in predicting hard clinical outcomes, including heart failure. These additional markers may be helpful in improving estimation of risk associated with decreased kidney function beyond current

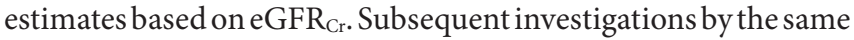
group using data from the ARIC study have reported significant associations between serum $\beta_{2} \mathrm{M}$ and sudden cardiac death (201) and fractures (119). Among the three biomarkers (Cr, BTP, and $\beta_{2} \mathrm{M}$ )-based CKD-EPI estimating equations, $\beta_{2} \mathrm{M}$ demonstrated the strongest association with sudden death [HR for fourth quartile vs. first quartile $3.48(2.03-5.96)$ vs. $\leq 2.7$ for the other kidney markers]. Renal filtration markers and albuminuria were shown to associate with fracture risk. Whereas the relationship between Cr-based CKD-EPI and risk of hospitalization for fracture was non-linear, there was a graded association between the inverse of serum $\beta_{2} \mathrm{M}$ (HR per 1-SD decrease, 1.26, 95\% CI, 1.15-1.37, $P<0.001)$. This risk was not attenuated and in fact increased when the investigators adjusted for the Cr-based eGFR $\mathrm{Cr}_{\mathrm{r}}$ to 1.37 (95\% CI: 1.24-1.51, $P<0.001$ ).

Therefore, when improved risk prediction (due to decreased GFR) is needed, serum $\beta_{2} \mathrm{M}$ can be utilized as an alternative filtration marker beyond $\mathrm{Cr}$. This finding was also independently reaffirmed in a subsequent prospective cohort study (202). In this study, the investigators sought to determine whether serum $\beta_{2} \mathrm{M}$ levels have a stronger association with all-cause and CV mortality-like cystatin $\mathrm{C}$ compared to $\mathrm{eGFR}_{\mathrm{Cr}}$ and to evaluate whether $\beta_{2} \mathrm{M}$ improved risk classification beyond $e \mathrm{GFR}_{\mathrm{Cr}}$, in a nationally representative sample of adults $(n=6,445)$ in the US. Both studies mentioned above were performed on samples from the general population.

\section{$\beta_{2} M$ IN ESRD}

A non-traditional risk factor for CV mortality is the accumulation and high serum levels of $\beta_{2} \mathrm{M}$ (195). The interpretation of the serum $\beta_{2} \mathrm{M}$ in patients with ESRD is complicated by the non-linear, bicompartmental kinetics, and large interindividual variability in kinetic parameters. This variability was recently quantified by our group in a patient-level meta-analysis of all studies reporting on kinetic parameters across the spectrum of CKD and ESRD (117). Using large-scale clinical trial simulations we showed that residual renal function is the major determinant of serum $\beta_{2} \mathrm{M}$ concentrations even in patients receiving maintenance dialysis (195). Furthermore, enhanced dialytic removal of $\beta_{2} \mathrm{M}$ will materially affect the biomarker's levels only when the residual renal clearance is less than $2 \mathrm{ml} / \mathrm{min}$. These model-derived predictions are in substantial agreement with a large body of clinical data. They also support the further development of serum $\beta_{2} \mathrm{M}$ as a measure of residual renal function in patients receiving renal replacement therapy. This topic has received some attention in the recent literature with some encouraging preliminary results $(132,203)$. In the following sections, we undertake an extensive review of the available literature 
regarding serum $\beta_{2} \mathrm{M}$ levels, delivered dialysis dose, method of clearance, and outcome measures. The key concepts behind the relevance of $\beta_{2} \mathrm{M}$ in this field are the (a) middle molecule hypothesis [which in turn has directed the development of many of these dialysis techniques using $\beta_{2} \mathrm{M}(204-209)$ as a proxy of other uremic toxins], (b) the lack of appreciation of the considerable effects of residual renal function in determining serum $\beta_{2} \mathrm{M}$ levels even in patients receiving the most advanced forms of these therapies, and (c) the strong associations between $\beta_{2} \mathrm{M}$ and outcomes (which rivals the magnitude of similar associations observed for other biomarkers, e.g., albumin) reported in these studies.

\section{Conventional Hemodialysis}

Observational studies originate strong message about the predictive power of serum $\beta_{2} \mathrm{M}$ (210). The prognostic implication of serum $\beta_{2} \mathrm{M}$ levels for the survival of HD patients was examined in 490 prevalent HD patients divided into two groups according to their serum $\beta_{2} \mathrm{M}$ levels (lower and higher $\beta_{2} \mathrm{M}$ group). During the follow-up period of $40 \pm 15$ months, there were 91 all-cause deaths (36 from CV causes). The results demonstrated that the serum $\beta_{2} \mathrm{M}$ level is a significant predictor of mortality in HD patients, independent of HD duration, diabetes, malnutrition, and chronic inflammation. This observational study provides a modest argument about the clinical importance of lowering serum $\beta_{2} M$ in patients receiving maintenance HD. Counter to this argument is a report on the relationship between serum $\beta_{2} \mathrm{M}$ and survival of chronic HD patients and of the association of serum $\beta_{2} \mathrm{M}$ levels with mortality (211). Surprisingly, this study showed that higher serum $\beta_{2} \mathrm{M}$ levels are associated with better survival in these patients. This paradoxical association may be a manifestation of "reverse epidemiology", since nutritional status was an independent predictor of serum $\beta_{2} \mathrm{M}$ concentration in the aforementioned study.

The association of inflammatory biomarkers and $\beta_{2} \mathrm{M}$ has been the focus of many studies during the 1990s before the development of modern synthetic dialyzers $(17,212-215)$. This partially contradictory literature suggests an association between inflammation, triggered by membrane material, and serum $\beta_{2} \mathrm{M}$ concentrations. To the extent that inflammation is a non-traditional factor for CV and overall mortality, as recently reviewed by Ref. (216), one would expect the association between serum $\beta_{2} \mathrm{M}$ and mortality to be partly attributed to the confounding role of inflammation. Nevertheless, there is a paucity of more modern studies examining the association between serum $\beta_{2} \mathrm{M}$ and risk factors for mortality in dialysis. A small study of 40 patients in high-flux (HF) HD for more than 6 months examined the association of serum $\beta_{2} \mathrm{M}$ with inflammation and dyslipidemia as $\mathrm{CV}$ risk factors (217). There was no correlation of serum $\beta_{2} \mathrm{M}$ with $\mathrm{C}$-reactive protein (CRP) and IL- 6 when HF membranes were used. During the follow-up period of 3 years, 6 out of 40 patients died from CV events. A significant relationship of $\beta_{2} \mathrm{M}$ with dyslipidemia and mineral bone disorders, but not with inflammation was observed. Along the same lines, other groups have reported associations of serum $\beta_{2} \mathrm{M}$ with suppressed interferon-gamma production, but not the traditional inflammatory marker of CRP when patients are switched from low flux (LF) to HF dialyzers $(218,219)$. These observations mirror similar findings in non-dialysis-dependent
CKD (198). Therefore, $\beta_{2} \mathrm{M}$ might have an important role in the development of $\mathrm{CV}$ diseases, independent of other traditional and non-traditional risk factors even when patients are dialyzed with highly permeable HF membranes. There is a need for large, modern studies in this era of HF dialyzers and ultrapure dialyzate to better understand the magnitude and significance of $\beta_{2} \mathrm{M}$ in patients receiving maintenance $\mathrm{HD}$.

Observational studies and randomized clinical trials (RCTs) suggest that $\mathrm{HF} H \mathrm{HD}$ efficiently removes $\beta_{2} \mathrm{M}$ from the blood and has positive effects on the survival and morbidity of uremic patients when compared with LF HD. The bulk of information [96\% of all patients and events in the most recent meta-analysis by the Cochrane group (220)] is provided by two large multicenter RCTs. The hemodialysis (HEMO) study was a RCT designed to examine the impact of two treatment parameters (dialysis dosage based on urea $\mathrm{Kt} / \mathrm{V}$ and membrane permeability) on clinical outcomes of maintenance HD patients (221). In the HEMO study, membrane flux was defined by the clearance of $\beta_{2} \mathrm{M}$ (surrogate for the clearance of middle molecules). The primary analysis of the HEMO study did not show a statistically significant reduction in the rate of the primary outcome and all-cause mortality. In secondary analyses, however, a $20 \%$ decrease in cardiac death was observed for the HF group compared with the LF group. In the subgroup of patients who had been on dialysis for $>3.7$ years before enrollment in HEMO, HF was associated with lower allcause mortality, cardiac deaths $(221,222)$, and cerebrovascular events (223). As expected, the cumulative mean predialysis serum $\beta_{2} \mathrm{M}$ level during follow-up in the HF arm was statistically significantly lower than that in the LF arms. Furthermore, predialysis serum $\beta_{2} \mathrm{M}$ levels predicted all-cause mortality even after adjustment for years on dialysis and residual kidney function (224). A subsequent, secondary analysis of HEMO examined the association of serum $\beta_{2} \mathrm{M}$ levels and dialyzer $\beta_{2} \mathrm{M}$ kinetics with the two most common causes of deaths in the HEMO study: cardiac and infectious diseases (225). In this report, the cumulative mean predialysis serum level of the middle molecule, $\beta_{2} \mathrm{M}$, correlated positively with the relative risk for infectious deaths in the HEMO study.

The Membrane Permeability Outcome (MPO) study is the second largest RCT to investigate the impact of membrane permeability on survival in incident HD patients. This study adopted a novel design, in that it specifically made a distinction between patients who had low albumin $(\leq 4 \mathrm{~g} / \mathrm{dl})$ and normal albumin $(>4 \mathrm{~g} / \mathrm{dl})$ as separate randomization groups (226). The target patient population in MPO was different from the HEMO cohort, which only enrolled patients with no residual renal function who had been on dialysis for more than 3 months. In MPO, patients with serum albumin $\leq 4 \mathrm{~g} / \mathrm{dl}$ had significantly better survival in the HF group compared with the LF group $(227,228)$. A post hoc secondary analysis showed that HF membranes may significantly improve survival in diabetic patients. No difference was found in patients with normal albumin levels. Our group reanalyzed the data from the HEMO and MPO studies to take into account dialyzer reuse in HEMO (reuse was not permitted in MPO). Our secondary analysis (229) reaffirmed the message from these two large, high-quality RCTs: HF dialysis with non-reused dialyzers was associated with an adjusted HR of 0.63 (95\% CI: 0.51-0.78), 
relative to their LF counterparts. Reductions of serum $\beta_{2} \mathrm{M}$ explained only one-third of the mortality benefit of the nonreused dialyzers in this report, raising the possibility that there are other, non- $\beta_{2} \mathrm{M}$ mediated, beneficial effects of HF dialysis.

Other investigations have attempted to shed a light into the non- $\beta_{2} \mathrm{M}$-related effects of $\mathrm{HF}$ dialysis. One recent study explored the effect of membrane flux on $\mathrm{CV}$ risk factors and on $\beta_{2} \mathrm{M}$ plasma levels in patients treated with extended dialysis (between 5 and $8 \mathrm{~h}$ for all patients). In this trial, patients were randomly assigned to the treatment sequences LF/HF dialysis vs. HF/LF dialysis in a crossover design after a 3-month run-in period, with each phase lasting 9 months (230). This study did not find an influence of HF filters on several traditional CV risk factors, despite the significant reduction of plasma $\beta_{2} \mathrm{M}$ levels at the end of the HF phase. At the time of this writing, the beneficial effects of $\mathrm{HF}$ dialysis on $\mathrm{CV}$ outcomes can only partly be attributed or explained to reductions in plasma $\beta_{2} \mathrm{M}$ levels, or even to improvements in immune function (218). Even though we do have firm evidence from the HEMO and MPO that therapies associated with more efficient dialytic removal of plasma $\beta_{2} \mathrm{M}$ will improve $\mathrm{CV}$ outcomes, reduction in the plasma levels of this marker only partly explain this effect.

Collectively, the bulk of available evidence highlights the potential of plasma $\beta_{2} \mathrm{M}$ and its higher removal to serve as biomarker of outcomes, particularly CV mortality, in patients receiving conventional thrice weekly dialysis. Pitfalls of reverse epidemiology, the less than perfect association of reduced plasma $\beta_{2} \mathrm{M}$ with survival, study limitations and finally the disparate effects of plasma $\beta_{2} \mathrm{M}$ in patients with hypoalbuminemia suggest that additional biomarkers are needed to both understand the effects of HF dialysis on clinical outcomes and provide a causal explanation about the role of $\beta_{2} \mathrm{M}$ in mediating these outcomes.

\section{Hemodiafiltration}

Online hemodiafiltration (OL-HDF), the most efficient renal replacement therapy, enables enhanced removal of small and large uremic toxins by combining diffusive and convective solute transport. Four meta-analyses of RCTs and narrative reviews in this area showed inconsistent results concerning the effect of convective treatments in improving general and CV survival. Nevertheless, these analyses suggest that OL-HDF may significantly reduce intradialytic symptomatic hypotension (231-236). Simulation studies anticipate that there should be a steep effect of convection volume (dose of OL-HDF) and achieved plasma $\beta_{2} \mathrm{M}$ levels in patients receiving HDF (117). These simulation results originate from measurements in actual patients receiving convective therapies (237). By inference, one would expect OL-HDF to be associated with improved survival in prevalent dialysis patients receiving higher convection volume. This hypothesis is supported by observational studies and secondary analyses of RCTs. This evidence, reviewed further below, indicates that the observed reduction in mortality associated with OL-HDF correlates with the convection volumes delivered. The Dialysis Outcomes and Practice Patterns Study, an observational study involving 2,165 patients, was the first to identify the role of convection volume in patient outcome (238). This study showed that 15-25 1 of substitution volume per session (not including weight loss for extracellular fluid control) resulted in a 35\% reduction in mortality with high-efficiency OL-HDF relative to LF HD.

The hypothesis of an effect of convective volume on outcomes was also explored in a post hoc fashion in the large HDF trials reported in the last 5 years. Although the CONTRAST Study, a RCT of OL-HDF vs. LF-HD involving 714 patients was not able to prove the superiority of OL-HDF over conventional LF HD in its primary end point of mortality, post hoc analysis identified that larger volumes of convection fluid were associated with a significant reduction in all-cause and CV mortality (239). The Turkish HDF Study (240) was a RCT involving 782 patients which compared survival rates for OL-HDF versus HF HD; again, no significant differences in primary end points were observed, but post hoc analysis indicated significantly reduced mortality in the subgroup of patients receiving the largest substitution volumes ( $>17.4 \mathrm{l} /$ session). Finally, the ESHOL Study, a prospective RCT comparing postdilution OL-HDF with HF-HD involving 906 prevalent patients, reported a $30 \%$ reduction in all-cause mortality, $33 \%$ in $\mathrm{CV}$ mortality, and $61 \%$ risk reduction in mortality from stroke (241). Interestingly, in this study a mean delivered convection volume of $23.7 \mathrm{l} /$ session was required to achieve this magnitude of reduction in mortality.

The convection volume threshold and the range associated with survival advantage were assessed in a large cohort of incident adult patients $(n=2,293)$ treated by postdilution OL-HDF over a 101-month period (237). The relative survival rate of OL-HDF patients, adjusted for age, gender, comorbidities, vascular access, albumin, CRP, and dialysis dose, was found to increase at about 55 l/week and to plateau at 70-75 1/week. Similar analysis of predialysis plasma $\beta_{2} \mathrm{M}$ concentrations found a nearly linear decrease as convection volume increased from 40 to $75 \mathrm{l} /$ week. Thus, a convection dose target based on convection volume should be considered and needs to be confirmed by prospective trials as a new determinant of dialysis adequacy in patients receiving convective therapies.

An individual pooled participant analysis of the largest trials mentioned above is in line with these observations (242), suggesting a better survival when a convection volume of at least 23 1/session was delivered. Nevertheless, none of the large convective therapies trials has targeted these high volumes. Since patients were not randomized to these high targets, it is very likely that the results of these post hoc analyses are strongly confounded by other factors (234). In particular, high convection volumes can only be achieved if the dialysis access can support a high enough flow rate to keep the dialysis filtration fraction at a safe range (less than 30\%). Participants with better functioning accesses and/or those receiving longer treatments, factors that are known to be linked to better patient outcomes, would thus have received higher convection volumes. Only well-designed RCTs with rigorous controlled convection volume targets can provide unambiguous evidence for the beneficial effects of higher convection volumes on outcomes.

\section{Hemofiltration}

Hemofiltration is a pure convective form of renal replacement therapy, which does not utilize a dialysis component. The effect of on-line high-flux hemofiltration (OL-HF hemofiltration) vs. 
LF HD on mortality in CKD was studied in a small RCT (243). They compared OL-HF hemofiltration with ultrapure LF HD, assessing survival and morbidity in patients with ESRD. It was an investigator-driven, prospective, multicenter, 3-year-follow-up, centrally randomized study with no blinding and based on the intention-to-treat principle. Prevalent patients with ESRD (age, 16-80 years; vintage $>6$ months) receiving renal replacement therapy at 20 Italian dialysis centers were included and centrally randomly assigned to HD $(n=32)$ or hemofiltration $(n=32)$. All-cause mortality, hospitalization rate for any cause, prevalence of dialysis hypotension, standard biochemical indexes, and nutritional status were monitored. There was significant improvement in survival with hemofiltration compared with HD (78\%, hemofiltration vs. 57\%, HD) at 3 years of follow-up after allowing for the effects of age $(P=0.05) . \beta_{2}$ M plasma levels remained constant in HD patients $(33.90 \pm 2.94 \mathrm{mg} / \mathrm{dl}$ at baseline and $36.90 \pm 5.06 \mathrm{mg} / \mathrm{dl}$ at 3 years), but decreased significantly in hemofiltration patients $(30.02 \pm 3.54 \mathrm{mg} / \mathrm{dl}$ at baseline vs. $23.9 \pm 1.77 \mathrm{mg} / \mathrm{dl} ; P<0.05)$. This was a small preliminary intervention study with a high dropout rate and problematic generalizability. They concluded that OL-HF hemofiltration may improve survival independent of $\mathrm{Kt} / \mathrm{V}$ in patients with ESRD, with a significant decrease in plasma $\beta_{2} \mathrm{M}$ levels and increased BMI. A larger study is required to confirm these results. Such a study could include an arm of higher volume OL-HDF in order to probe the differential effects (if any) of pure convection vs. mixed convection/diffusion in achieving lower plasma $\beta_{2} \mathrm{M}$ levels and improving patient outcomes.

\section{Peritoneal Dialysis (PD)}

The association of $\beta_{2} \mathrm{M}$ and patient survival in patients receiving $\mathrm{PD}$ is underexplored. In the largest observational study to date 771 PD patients were selected from the Clinical Research Center registry for ESRD cohort in Korea in order to examine the association of serum $\beta_{2} \mathrm{M}$ levels with all-cause mortality (244). The patients were categorized into three groups by tertiles of serum $\beta_{2} \mathrm{M}$ levels, and the median follow-up period was 39 months. The all-cause mortality rate was significantly different according to tertiles of serum $\beta_{2} \mathrm{M}$ in PD patients $(P=0.03)$. Multivariate Cox proportional analysis showed that the HR for all-cause mortality was $1.02(95 \%$ CI $1.01-1.04, P=0.006)$ per $1 \mathrm{mg} / \mathrm{l}$ increase in serum $\beta_{2} \mathrm{M}$ after adjustment for multiple confounding factors that relate to malnutrition and for inflammation markers. However, serum $\beta_{2} \mathrm{M}$ was not associated with all-cause mortality after adjustment for residual renal clearance. Even though these results are supportive of the potential role of the serum $\beta_{2} \mathrm{M}$ level as a predictor of mortality in $\mathrm{PD}$, they suggest that this association is a reflection of the residual renal function, a powerful predictor of mortality in patients receiving PD (245-247).

The effects of higher peritoneal clearance of serum $\beta_{2} \mathrm{M}$ on mortality in PD patients are much less certain. Relevant data come from a study which investigated whether baseline peritoneal loss and clearance of albumin and other proteins is a risk factor of death (248). Mass-transfer area coefficient of $\mathrm{Cr}$ and peritoneal clearances of albumin, $\beta_{2} \mathrm{M}, \alpha_{2}$-macroglobulin, and IgG were calculated during a standard peritoneal permeability analysis. The total amount of albumin loss in the dialysate was also calculated. Overall mortality was studied with an intentionto-treat analysis. High baseline albumin clearance was associated with fast transport status, the presence of peripheral arterial disease, and a high comorbidity index, whereas CRP did not differ from the patients with low albumin clearance. Age, high comorbidity score, CRP $>10 \mathrm{mg} / \mathrm{l}$, and a low serum albumin were associated with mortality. Peritoneal albumin clearances and albumin loss were not associated with death in crude and adjusted analysis. Similarly, peritoneal clearances of $\operatorname{IgG}, \alpha_{2}-$ macroglobulin, and $\beta_{2} \mathrm{M}$ were not determinants of survival. They concluded that baseline peritoneal albumin and protein clearances are associated with signs of comorbidity, but this does not have a measurable effect on patient survival. However, these findings are tempered by the fact that higher clearances are associated with a fast-transport phenotype, which itself is a predictor of worse outcomes in PD $(249,250)$. Future studies should examine the effects of PD clearance irrespective of membrane transport status to better clarify the role of $\beta_{2} \mathrm{M}$ and its clearance in PD.

\section{$\beta_{2} M$ IN KIDNEY TRANSPLANTATION}

Chronic allograft damage is still a leading cause of graft failure 1 -year posttransplantation (251). The pathophysiology of this entity is still not clearly understood but both alloantigen-dependent and alloantigen-independent factors act together to initiate inflammatory reactions that eventually lead to loss of nephrons followed by interstitial fibrosis and tubular atrophy (IF/TA) in the graft (252). Alloantigen-dependent factors that can lead to chronic allograft damage include recurrent T-cell-mediated rejection, antibody-mediated rejection, and the presence of donor-specific antibodies (253). Alloantigen-independent factors that can lead to chronic allograft damage include ischemia/reperfusion injury, donor age, arterial hypertension of the donor, drug toxicity, infections, diabetes and hypertension in the recipient, recurrent and de novo glomerular disease, and the presence of proteinuria.

Non-invasive diagnostic studies that may help in determining whether chronic allograft damage is present include monitoring for proteinuria, monitoring for donor specific antibodies, and monitoring for changes in the serum creatinine (254-257). But none of these tests are specific for making a diagnosis of chronic allograft damage, and elevations in serum creatinine lag behind the histological changes observed in chronic allograft damage. Thus, identifying urinary biomarkers that can detect early tubular injury would be beneficial in helping to identify those patients who need an allograft biopsy earlier on so that further progression of chronic allograft damage is prevented. Similar to the available evidence from patients with non-transplant CKD, serum $\beta_{2}$ M-based eGFR ( $<30$ vs. $>60 \mathrm{ml} / \mathrm{min}$ ) has been found to predict CV events [HR: $2.56(95 \%$ CI: $1.35-4.88 ; P=0.004)$ ], overall mortality [HR: 4.09 (95\% CI: 2.21-7.54; $P<0.001)$ ], and dialysis dependent kidney failure [HR: 15.53 (95\% CI: 6.99-34.51; $P<0.001$ )] in allograft recipients (258). The predictive ability of elevations in serum $\beta_{2} \mathrm{M}$ for subsequent allograft loss has also been reported by other groups (259). Many de novo donor-specific antibodies recognize free serum $\beta_{2} \mathrm{M}$ (260), but the significance of this association, i.e., whether it simply reflects false-positive reactions (more likely) or it is pathophysiologically significant (less likely) remains to be established. 


\section{Urinary $\beta_{2} \mathbf{M}$ As a Biomarker in Chronic Allograft Damage}

Proteomic analysis has been used in various studies in an attempt to identify a protein biomarker pattern that can help reveal chronic allograft damage. A very promising approach (261) used surfaced-enhanced laser-desorption/ionization time-of-flight mass spectrometry (SELDI-TOF-MS) to identify urinary proteins as biomarkers for chronic allograft damage. In this retrospective study, there were 34 renal transplant patients (disease group) with histologically proven chronic allograft damage, with an eGFR less than $45 \mathrm{ml} / \mathrm{min}$ who were more than 1-year posttransplantation. These patients were compared to a "control" group of 36 renal transplant patients with normal renal function (eGFR $>50 \mathrm{ml} / \mathrm{min}$ ). Significantly higher concentrations of $\beta_{2} \mathrm{M}$ were observed in the urine of the patients with chronic allograft damage compared with the controls (261). In another study (262), using the same population as that in Ref. (261), OrbiTrap mass spectrometry was utilized to analyze the urine further for identification of more biomarkers specific to chronic allograft damage. Again $\beta_{2} \mathrm{M}$ was shown to be significantly increased in chronic allograft damage, with an approximately 50 -fold increase of $\beta_{2} \mathrm{M}$ expression in this cohort compared to the control group $(P<0.0001)$. Other proteins that were significantly increased in the chronic allograft damage cohort were clusterin and NGAL. Apolipoprotein A1 and uromodulin levels were significantly decreased in the same cohort compared to the control group (262).

Despite these encouraging observations, we currently lack a firm understanding of the pathophysiological processes underlying chronic urinary $\beta_{2} \mathrm{M}$ elevations in kidney transplant recipients. One possibility is that they reflect chronic immunological injury. This is certainly possible, since urinary $\beta_{2} \mathrm{M}$ is increased in patients with acute rejection. A previous study using unbiased proteomic analysis (SELDI-TOF-MS) identified many urinary fragments in the mass/charge $(\mathrm{m} / \mathrm{z}$ ) region 5,270-5,550 (region I; five peaks), 7,050-7,360 (region II; three peaks), and 10,53011,100 (region III; five peaks) that always occurred together; the normal urine pattern had no peak clusters in these $\mathrm{m} / \mathrm{z}$ regions (263). Interestingly, about $18 \%$ of patients with stable allograft function exhibited this pattern. A follow-up investigation by the same group used liquid chromatography-mass spectroscopy techniques to identify these peaks as cleaved $\beta_{2} \mathrm{M}$. The authors concluded that fragmented urinary $\beta_{2} \mathrm{M}$ can serve as a potential biomarker for acute tubular injury due to rejection in renal allografts (264). The association of urinary $\beta_{2} \mathrm{M}$ with acute rejection has been noted in two other unbiased proteomic studies utilizing matrix-associated laser desorption ionization time-of-flight mass spectroscopy $(265,266)$ by the same group. Whereas the first study suggested specificity for acute rejection, the second one did not, as $\beta_{2} \mathrm{M}$ elevations were also seen in patients with non-transplant forms of CKD. Interestingly, another group reported that urinary $\beta_{2} \mathrm{M}$ is elevated in renal transplant recipients even in the setting of good allograft function; this was different from patients with non-transplant-associated CKD who had high urinary $\beta 2 \mathrm{M} \mathrm{lev-}$ els only when the Cr clearance was less than $30 \mathrm{ml} / \mathrm{min} / 1.73 \mathrm{~m}^{2}$ (267). One could postulate that elevations in urinary $\beta_{2} \mathrm{M}$ in the absence of changes in serum $\mathrm{Cr}$ could be used to detect acute rejection early. Furthermore, chronic elevations in urinary $\beta_{2} \mathrm{M}$ could reflect ongoing low-grade immunological injury, leading to IF/TA and eventually to allograft loss. Larger studies are needed to obtain a better understanding of the factors affecting urinary $\beta_{2} \mathrm{M}$ and its determinants in renal transplant recipients.

In summary, urinary $\beta_{2} \mathrm{M}$ may be sensitive for this entity, but further research in this area is needed to identify whether it can be used as a reliable biomarker for identifying patients with early chronic allograft damage due to immunological factors who need an allograft biopsy for the effective management of this complex disease process.

\section{$\beta_{2} M$ IN NON-RENAL DISEASES}

Not only the pathology related to renal disease but also non-renal etiologies have influence on serum $\beta_{2} \mathrm{M}$ level. Higher serum $\beta_{2} \mathrm{M}$ level can be seen in patients smoking, of non-black race, and with a higher amount of protein excretion in the urine (133). As $\beta_{2} \mathrm{M}$ is a light chain subunit of MHC class I antigens, it is present in all nucleated cells, especially on immunocompetent cells such as macrophages, active T and B lymphocytes. During normal cell turn over, it is released into the body fluids. Pathologies with high cell turnover, such as hemato-oncological conditions, and rheumatologic diseases are associated with higher serum $\beta_{2} \mathrm{M}$ levels $(268,269)$. As many of these conditions may be associated with the subsequent development of CKD (270-272), we will briefly review some of these associations. Our aim is not to compile an exhaustive presentation of this large and rapidly expanding literature. Rather, we aim to draw attention to representative reports from other areas of Internal Medicine and highlight the relevant key messages for Nephrologists.

\section{Hemato-Oncological Pathology}

In hematological malignancies, such as leukemia, lymphoma, and multiple myeloma, serum $\beta_{2} \mathrm{M}$ level is found to be elevated, despite preserved renal function. It has been reported that $60 \%$ of patients with mantle cell lymphoma have high pretreatment serum $\beta_{2}$ M level (273). This elevated value is independently associated with unfavorable prognosis of most of the hematological malignancies $(269,273-277)$. These associations persist despite adjustment for well-validated clinical prognostic scores and therapy indicators $(274,278,279)$.

In multiple myeloma, serum $\beta_{2} \mathrm{M}$ level is the main determinant of the International Staging System (ISS, Stage I: $\beta_{2} \mathrm{M}<3.5 \mathrm{mg} /$ $\mathrm{dl}$ and albumin $>3.5 \mathrm{~g} / \mathrm{dl}$, Stage II: $\beta_{2} \mathrm{M}>3.5$ but less than $5.5 \mathrm{mg} / \mathrm{dl}$ or $\beta_{2} \mathrm{M}<3.5 \mathrm{mg} / \mathrm{l}$ and albumin $<3.5 \mathrm{~g} / \mathrm{dl}$, Stage III $\left.\beta_{2} \mathrm{M}>5.5 \mathrm{mg} / \mathrm{l}\right) . \beta_{2} \mathrm{M}$ predicts not only the prognosis but also the progression of asymptomatic disease (HR 3.30; $P=0.002$ ) (280) and even outcomes after stem cell transplantation $(281,282)$. The association between serum $\beta_{2} \mathrm{M}$ and albumin upon patient prognosis in myeloma, not only is reminiscent of similar associations noted in the dialysis literature but also is very robust statistically. Even recent proposals for a revised ISS (283) based on emerging biomarkers (e.g., chromosomal abnormalities) or the levels of soluble free light chains (284) have highlighted the prognostic significance of high serum $\beta_{2} \mathrm{M}$ levels. Although the 
association between $\beta_{2} \mathrm{M}$ and prognosis has been interpreted to reflect a higher tumor burden in myeloma (285) or a more aggressive $(286,287)$ myeloma subtype, it is important to realize that renal insufficiency may underline at least in part the higher levels of serum $\beta_{2} \mathrm{M}$ seen in this disease (288). Despite the different cell origin, chronic leukocytic leukemia recapitulates the findings from multiple myeloma. $\beta_{2} \mathrm{M}$ is a well-recognized adverse prognostic factor in this disease (289-291); even though one would expect the utility of this marker to be higher at the latter than the earlier stage of this disease, this hypothesis is not entirely borne out by observations (290). Even patients with early-stage disease have elevated serum level of $\beta_{2} \mathrm{M}$, which may reflect more aggressive behavior of the malignant process. This alternative hypothesis, i.e., that serum elevations of this biomarker may reflect the combination of higher tumor burden and more aggressive biology, is supported by observations that higher serum levels of $\beta_{2} \mathrm{M}$ are associated with shorter time to therapy (291). Furthermore, failure to normalize serum $\beta_{2} \mathrm{M}$ after 6 months of kinase inhibitor therapy (ibrutinib) was associated with inferior progression-free survival [HR 16.9 (95\% CI: 1.3220.0), $P=0.031$ ] for ibrutinib-treated patients. This association persisted after multivariate adjustments (292).

Elevated serum $\beta_{2} \mathrm{M}$ level can also be seen in patients with solid cancers, such as ovarian cancer (293), gall bladder cancer (294), prostate cancer (295), breast cancer (296), and renal cell carcinoma (297). Its higher value is closely related to the poor prognosis and aggressive characteristics of the tumor (293-297). Due to the high prevalence of high $\beta_{2} \mathrm{M}$ in patients with ovarian cancer, $\beta_{2} \mathrm{M}$ has been incorporated into the FDA approved OVA1 multianalytes assay for risk stratification of adnexal masses $(298,299)$. OVA1 measures the serum levels of five analytes, CA125, transthyretin, apolipoprotein A1, transferrin, and $\beta_{2} \mathrm{M}$. Results are reported as high or low risk for ovarian cancer and are used to determine whether referral to gynecologic oncology is required prior to surgical treatment of an adnexal mass.

More recently, evidence has emerged that implicates serum $\beta_{2} \mathrm{M}$ level as a global biomarker of occult malignancy [HR: 1.25 (95\% CI: $1.06-1.47 ; P=0.002$ for the trend of higher risk with increasing $\beta_{2} \mathrm{M}$ quartile)], and more narrowly colorectal cancer risk [HR: 2.21 (95\% CI: $1.32-3.70 ; P=0.001$ for the trend of higher risk with increasing $\beta_{2} \mathrm{M}$ quartile)]. These associations, which were not attenuated after adjustment for an inflammatory biomarker, CRP, or even renal function (eGFR) of 12,300 patients, were noted in the prospective ARIC study. Significant associations were also observed for mortality from total, lung, and hematological cancers (300).

\section{Autoimmune Disease}

Serum $\beta_{2} \mathrm{M}$ is elevated in autoimmune diseases as well. Higher serum levels are seen in patients with systemic lupus erythematosus and adult-onset Still disease, especially in those with active diseases and hemophagocytic syndrome $(268,301)$. After therapy, the serum $\beta_{2} \mathrm{M}$ level decreased significantly (268). Urinary $\beta_{2} \mathrm{M}$ has been shown to correlate with overall and renal disease activity scores and proteinuria (164). Patients with active primary Sjögren's syndrome, notably those with increased systemic disease activity (302) and history of lymphoma (303, 304), and hemophagocytic lymphohistiocytosis (305) were also found to have elevated urinary $\beta_{2} \mathrm{M}$ level. Interestingly, higher levels of urinary $\beta_{2} \mathrm{M}$ are found in patients with active primary Sjögren's syndrome and impaired eGFR (306).

\section{$\beta_{2}$ M: SYNTHESIS AND THE WAY FORWARD}

In this review, we examined the recent literature linking elevated serum circulating and urinary $\beta_{2} \mathrm{M}$ levels to outcomes across the spectrum of renal impairment and also its role as biomarker in non-renal diseases. This literature suggests that $\beta_{2} \mathrm{M}$ may be a particularly strong (sensitive) biomarker for both morbidity and mortality across numerous clinical conditions. This lack of specificity for particular clinical states, necessitates the application of a suitable context that would allow the interpretation of alterations in serum and/or urinary $\beta_{2} \mathrm{M}$ levels. Such a framework would by necessity be context specific given the ubiquity in expression of $\beta_{2} \mathrm{M}$. For future applications in non-dialysis-dependent CKD, such a model would most likely have to incorporate additional biomarkers to derive a complex, multivariate measurement of renal function. Existing approaches such as the combined $\beta_{2} \mathrm{M}$ and BTP formula referenced previously (199) show one possible research thread that may yield fruitful results. Nevertheless, it is worth remembering that the concentrations of several LMWP's retained in CKD are poorly predicted by different eGFR formulas in a CKD population (stages $2-5$ not on dialysis) (307). If this is indeed the case, then one may not improve much upon existing estimating equations through simple formulas based on biomarker level averaging, e.g., as was done when developing the cystatin-C/Cr eGFR (308) and $\beta_{2} \mathrm{M}-\mathrm{BTP}$ formulas (123). This raises the question of alternative approaches for the full subsequent development of $\beta_{2} \mathrm{M}$ as a biomarker in CKD.

We believe that the way forward for $\beta_{2} \mathrm{M}$ should be based on quantitative models for generation (non-renal determinants) and elimination (renal determinants) of this biomarker. For example, the population kinetic model we put forward (117) for the exploration of the "middle molecule" hypothesis for uremic toxicity maintains the separation between the processes of generation and elimination, while generating predictions that verify clinical observations in the dialysis population. When applied outside its intended application domain, i.e. in the field of $\mathrm{CKD}$, it generates predictions that should be contrasted against the relationship between plasma $\beta_{2} \mathrm{M}$ and the measured GFR estimated from extensive database analyses. Hence this model, developed on fewer than 150 patients, who were nonetheless extensively phenotyped, draws attention for further research on the generation (non-renal determinant) mechanisms that affect the serum levels of $\beta_{2} \mathrm{M}$.

Future research should expand this model to account for changes in the concentration of $\beta_{2} \mathrm{M}$ in the urine. Such studies are urgently needed, because the urinary $\beta_{2} \mathrm{M}$ appears to have a much larger utility than previously recognized. Animal toxicology experiments conducted under rigorously controlled 
conditions $(160,162)$ and provocative observations in glomerular diseases $(163,164)$ suggest that urinary $\beta_{2} \mathrm{M}$ may in fact be a better marker of glomerular than tubular damage. This finding, backed by controlled experiments in hundreds of animals and observations in a much smaller number of humans, seems to go against textbook dogma. The latter, however, is based on a handful of observations (20 normal, 15 with glomerular, and 15 with tubular pathology due to cadmium poisoning and hereditary syndromes) made 50 years ago at the dawn of the clinical chemistry and renal pathology and before the complex $\beta_{2} \mathrm{M}$-dependent mechanisms of protein transport in the kidney were deciphered (141). It is high time that studies acknowledging the biology of $\beta_{2} \mathrm{M}$ and its complex compartmental kinetics in serum and urine are undertaken so that the role of $\beta_{2} \mathrm{M}$ as a biomarker be clarified. The outcomes of this exercise are not merely academic and are not limited to the field of Nephrology, considering the importance of $\beta_{2} \mathrm{M}$ in other fields (mainly hematological oncology). Furthermore, this re-examination has the potential to link $\beta_{2} \mathrm{M}$ to another important biomarker, albumin whose kinetics and biofluid levels are controlled by $\beta_{2} \mathrm{M}$ through the FcRn.

At this point, we would like to put forward a hypothesis that we think ties together many observations in both CKD and ESRD: the emergence of non-renal processes as determinants of serum $\beta_{2} \mathrm{M}$ levels as renal function declines and the beneficial effects of HF-HD dialysis in patients with hypoalbuminemia as highlighted by reports from our group $(229,309)$. We hypothesize that this higher generation comes not from high cell turnover, e.g., as in oncological conditions, but from altered cell binding of $\beta_{2} \mathrm{M}$ to the many proteins that it chaperones. According to the model, the level of renal function is the main determinant of plasma $\beta_{2} \mathrm{M}$ concentrations by affecting both removal (glomerular filtration) and generation of free $\beta_{2} \mathrm{M}$. Interference with the binding of $\beta_{2} \mathrm{M}$ to $\mathrm{MHC}$ and non-classical MHC molecules [possibly in the endosomes where these interactions are initiated $(310,311)]$ by other uremic retention solutes constitutes a major source for the heightened generation of $\beta_{2} \mathrm{M}$ in uremia. Clinical manifestations of these alterations result both from the higher concentrations of $\beta_{2} \mathrm{M}$ (e.g., DRA) as well as the altered MHC/non-classical MHC function, i.e., the phenotype of $\beta_{2} \mathrm{M}$ deficiency highlighted in the $\beta_{2} \mathrm{M}$ knockout mice. Observations in these animals parallel the clinical observations and laboratory associations in patients with renal dysfunction: dysregulated IFN- $\gamma$ production $(312,313)$, tuberculosis (314-316), acute infections, and suboptimal antibody responses [all reviewed in Ref. (317)]. Patients with renal dysfunction or on dialysis have also a higher incidence of tumors that are considered to be of viral origin in registry studies (318-323). According to this model, the hypoalbuminemia seen in many dialysis patients is a reflection of a widespread abnormality in albumin rescue through the FcRn.

This hypothesis could provide an explanation for the beneficial effects of HF-HD in hypoalbuminemic patients. Although suggested by some in vitro studies $(324,325)$, other ex vivo $(326,327)$ and in vivo (328) investigations did not demonstrate an effect of flux on $\beta_{2} \mathrm{M}$ gene transcription or protein expression. On the other hand, both in vitro (329) and in vivo (328) flow cytometric studies have shown that dialysis with LF membranes is associated with a larger dissociation of $\beta_{2} \mathrm{M}$ from the HLA-I complex compared to their HF-HD counterparts. To the extent that this model is true, it would provide a partial molecular explanation for the clinical associations between higher $\beta_{2} \mathrm{M}$ concentrations (greater disruption of $\beta_{2} \mathrm{M}$ binding) and infectious mortality $(210,224,225)$. This model yields hypotheses about the binding behavior of $\beta_{2} \mathrm{M}$ to its targets, and the resultant regulation of biological processes, e.g., IFN- $\gamma$ and immunoglobulin levels in relation to higher clearance (renal or dialytic), which can tested in small randomized crossover studies and laboratory experiments $(218,313$, $329,330)$. In that regard, a "candidate toxin" approach based on the EUToX Uremic Solutes Database (331) could provide a way to test a number of known toxins in vitro experiments for a disruptive effect on the protein complexes of $\beta_{2} \mathrm{M}$. Given the potent effect of inflammatory stimuli on the function of the $\mathrm{MHC} / \beta_{2} \mathrm{M}$ system, future work in this area should attempt to control for the confounding effects of microinflammation, which is prevalent in dialysis patients, as well as possible dialysis membrane-immune system interactions.

\section{CONCLUSION}

In conclusion, $\beta_{2} \mathrm{M}$ is a promising marker to assess glomerular and tubular function in adults. It has similar performance to the Cr-based estimating equations as a measure of renal function, but may be more strongly associated with CV morbidity and mortality than $\mathrm{Cr}$, or other small molecular renal filtration markers. $\beta_{2} \mathrm{M}$ is also an important, emerging biomarker in numerous non-renal diseases. Plasma and urinary $\beta_{2} \mathrm{M}$ levels can be reliably and cost effectively measured, which makes it an ideal screening tool. Plasma and urinary $\beta_{2} \mathrm{M}$ levels can increase in certain conditions, which might limit its efficacy as a diagnostic marker in these populations. Future studies should be undertaken with the aim to link alterations in plasma and urinary $\beta_{2} \mathrm{M}$ levels to its renal and non-renal determinants and also to the levels of albumin, which is regulated by the complex of the $\beta_{2} \mathrm{M}-\mathrm{FcRn}$.

\section{AUTHOR CONTRIBUTIONS}

Each author was assigned a particular subtopic within this review. They researched the literature independently and provided their contribution to the corresponding author who integrated the manuscript. CA: conceived the paper idea, researched the biology and genetic disorders of $\beta_{2} \mathrm{M}$, animal toxicology studies, the kinetic model, and compiled the manuscript. SSC: researched the literature about non-renal diseases. Y-HN: researched the pediatric nephrology literature. M-ER: researched the literature of renal replacement therapies and the outcome studies in CKD. She also generated the first draft of the manuscript. KS: researched the literature on the use of the biomarker for glomerular and tubular disorders. PS: researched the literature on renal transplantation. AT critically reviewed the manuscript and drafted the response to author comments. All the authors were responsible for reviewing the final version of the article that was submitted to the journal. 


\section{REFERENCES}

1. USRDS. USRDS 2015 Annual Data Report: Atlas of Chronic Kidney Disease and End-Stage Renal Disease in the United States. Bethesda, MD: National Institutes of Health, National Institute of Diabetes and Digestive and Kidney Diseases (2015).

2. Brosius FC, Hostetter TH, Kelepouris E, Mitsnefes MM, Moe SM, Moore MA, et al. Detection of chronic kidney disease in patients with or at increased risk of cardiovascular disease: a science advisory from the American Heart Association Kidney and Cardiovascular Disease Council; the Councils on High Blood Pressure Research, Cardiovascular Disease in the Young, and Epidemiology and Prevention; and the Quality of Care and Outcomes Research Interdisciplinary Working Group: developed in collaboration with the National Kidney Foundation. Hypertension (2006) 48:751-5. doi:10.1161/ CIRCULATIONAHA.106.177321

3. Coca SG, Ismail-Beigi F, Haq N, Krumholz HM, Parikh CR. Role of intensive glucose control in development of renal end points in type 2 diabetes mellitus: systematic review and meta-analysis intensive glucose control in type 2 diabetes. Arch Intern Med (2012) 172:761-9. doi:10.1001/archinternmed.2011.2230

4. Estacio RO, Jeffers BW, Hiatt WR, Biggerstaff SL, Gifford N, Schrier RW. The effect of nisoldipine as compared with enalapril on cardiovascular outcomes in patients with non-insulin-dependent diabetes and hypertension. $N$ Engl J Med (1998) 338:645-52. doi:10.1056/NEJM199803053381003

5. ACCORD Study Group; Cushman WC, Evans GW, Byington RP, Goff DC, Grimm RH, et al. Effects of intensive blood-pressure control in type 2 diabetes mellitus. N Engl J Med (2010) 362:1575-85. doi:10.1056/NEJMoa1001286

6. Parving H-H, Brenner BM, McMurray JJV, de Zeeuw D, Haffner SM, Solomon SD, et al. Cardiorenal end points in a trial of aliskiren for type 2 diabetes. N Engl J Med (2012) 367:2204-13. doi:10.1056/NEJMoa1208799

7. ONTARGET Investigators, Yusuf S, Teo KK, Pogue J, Dyal L, Copland I, et al. Telmisartan, ramipril, or both in patients at high risk for vascular events. N Engl J Med (2008) 358:1547-59. doi:10.1056/NEJMoa0801317

8. Fried LF, Emanuele N, Zhang JH, Brophy M, Conner TA, Duckworth W, et al. Combined angiotensin inhibition for the treatment of diabetic nephropathy. N Engl J Med (2013) 369:1892-903. doi:10.1056/NEJMoa1303154

9. Jadoul M, Garbar C, van Ypersele de Strihou C. Pathological aspects of beta(2)-microglobulin amyloidosis. Semin Dial (2001) 14:86-9. doi:10.1046/j.1525-139x.2001.00037.x

10. Labriola L, Jadoul M. Dialysis-related amyloidosis: is it gone or should it be? Semin Dial (2017) 30(3):193-6. doi:10.1111/sdi.12590

11. Scarpioni R, Ricardi M, Albertazzi V, De Amicis S, Rastelli F, Zerbini L. Dialysis-related amyloidosis: challenges and solutions. Int J Nephrol Renovasc Dis (2016) 9:319-28. doi:10.2147/IJNRD.S84784

12. Copeland SD. Amyloidosis and its impact on patients with ESRD. Nephrol Nurs J (2006) 33:31-3.

13. Danesh F, Ho LT. Dialysis-related amyloidosis: history and clinical manifestations. Semin Dial (2001) 14:80-5. doi:10.1046/j.1525-139x.2001.00035.x

14. Gal R, Korzets A, Schwartz A, Rath-Wolfson L, Gafter U. Systemic distribution of beta 2-microglobulin-derived amyloidosis in patients who undergo longterm hemodialysis. Report of seven cases and review of the literature. Arch Pathol Lab Med (1994) 118:718-21.

15. Jadoul M, Garbar C, Noël H, Sennesael J, Vanholder R, Bernaert P, et al. Histological prevalence of $\beta 2$-microglobulin amyloidosis in hemodialysis: a prospective post-mortem study. Kidney Int (1997) 51:1928-32. doi:10.1038/ ki.1997.262

16. Jadoul M, Garbar C, Vanholder R, Sennesael J, Michel C, Robert A, et al. Prevalence of histological beta2-microglobulin amyloidosis in CAPD patients compared with hemodialysis patients. Kidney Int (1998) 54:956-9. doi:10.1046/j.1523-1755.1998.00064.x

17. Miyata T, Inagi R, Iida $\mathrm{Y}$, Sato M, Yamada N, Oda O, et al. Involvement of beta 2-microglobulin modified with advanced glycation end products in the pathogenesis of hemodialysis-associated amyloidosis. Induction of human monocyte chemotaxis and macrophage secretion of tumor necrosis factoralpha and interleukin-1. J Clin Invest (1994) 93:521-8. doi:10.1172/JCI117002

18. Yamamoto S, Gejyo F. Historical background and clinical treatment of dialysis-related amyloidosis. Biochim Biophys Acta (2005) 1753:4-10. doi:10.1016/j.bbapap.2005.09.006

19. Campistol JM. Dialysis-related amyloidosis after renal transplantation. Semin Dial (2001) 14:99-102. doi:10.1046/j.1525-139x.2001.00038.x
20. Grubb A, Simonsen O, Sturfelt G, Truedsson L, Thysell H. Serum concentration of cystatin $\mathrm{C}$, factor D and beta 2-microglobulin as a measure of glomerular filtration rate. Acta Med Scand (1985) 218:499-503. doi:10.1111/ j.0954-6820.1985.tb08880.x

21. Grubb A. Diagnostic value of analysis of cystatin C and protein HC in biological fluids. Clin Nephrol (1992) 38(Suppl 1):S20-7.

22. Norlund L, Fex G, Lanke J, Von Schenck H, Nilsson JE, Leksell H, et al. Reference intervals for the glomerular filtration rate and cell-proliferation markers: serum cystatin C and serum beta 2-microglobulin/cystatin C-ratio. Scand J Clin Lab Invest (1997) 57:463-70. doi:10.3109/00365519709084595

23. Corlin DB, Heegaard NHH. $\beta(2)$-microglobulin amyloidosis. Subcell Biochem (2012) 65:517-40. doi:10.1007/978-94-007-5416-4_19

24. Heegaard NHH. $\beta 2$-microglobulin: from physiology to amyloidosis. Amyloid (2009) 16:151-73. doi:10.1080/13506120903151775

25. Stoppini M, Bellotti V. Systemic amyloidosis: lessons from $\beta 2$-microglobulin. J Biol Chem (2015) 290:9951-8. doi:10.1074/jbc.R115.639799

26. Eichner T, Radford SE. Understanding the complex mechanisms of $\beta 2$ microglobulin amyloid assembly. FEBS J (2011) 278:3868-83. doi:10.1111/ j.1742-4658.2011.08186.x

27. Winchester JF, Salsberg JA, Levin NW. Beta-2 microglobulin in ESRD: an in-depth review. Adv Ren Replace Ther (2003) 10:279-309. doi:10.1053/j. arrt.2003.11.003

28. Berggård I, Bearn AG. Isolation and properties of a low molecular weight 32-globulin occurring in human biological fluids. J Biol Chem (1968) 243: 4095-103.

29. Becker JW, Reeke GN. Three-dimensional structure of beta 2-microglobulin. Proc Natl Acad Sci USA (1985) 82:4225-9. doi:10.1073/pnas.82.12.4225

30. Iwata K, Matsuura T, Sakurai K, Nakagawa A, Goto Y. High-resolution crystal structure of beta2-microglobulin formed at pH 7.0. J Biochem (2007) 142:413-9. doi:10.1093/jb/mvm 148

31. Cox J, Yewdell J, Eisenlohr L, Johnson P, Bennink J. Antigen presentation requires transport of MHC class I molecules from the endoplasmic reticulum. Science (1990) 247:715-8. doi:10.1126/science.2137259

32. Perarnau B, Siegrist C-A, Gillet A, Vincent C, Kimura S, Lemonnier FA. Beta 2-microglobulin restriction of antigen presentation. Nature (1990) 346:751-4. doi:10.1038/346751a0

33. Yamaguchi H. Association of MR1 protein, an MHC class I-related molecule, with ß2-microglobulin. Biochem Biophys Res Commun (2002) 290:722-9. doi:10.1006/bbrc.2001.6277

34. Clements CS, Kjer-Nielsen L, McCluskey J, Rossjohn J. Structural studies on HLA-G: implications for ligand and receptor binding. Hum Immunol (2007) 68:220-6. doi:10.1016/j.humimm.2006.09.003

35. Gonen-Gross T, Achdout H, Arnon TI, Gazit R, Stern N, Horejsi V, et al. The CD85J/leukocyte inhibitory receptor-1 distinguishes between conformed and \{beta\}2-microglobulin-free HLA-G molecules. JImmunol (2005) 175:4866-74. doi:10.4049/jimmunol.175.8.4866

36. Roopenian DC, Akilesh S. FcRn: the neonatal Fc receptor comes of age. Nat Rev Immunol (2007) 7:715-25. doi:10.1038/nri2155

37. Pyzik M, Rath T, Lencer WI, Baker K, Blumberg RS. FcRn: the architect behind the immune and nonimmune functions of IgG and albumin. J Immunol (2015) 194:4595-603. doi:10.4049/jimmunol.1403014

38. Chaudhury C, Mehnaz S, Robinson JM, Hayton WL, Pearl DK, Roopenian DC, et al. The major histocompatibility complex-related $\mathrm{Fc}$ receptor for IgG (FcRn) binds albumin and prolongs its lifespan. J Exp Med (2003) 197:315-22. doi:10.1084/jem.20021829

39. Pratheek BM, Nayak TK, Sahoo SS, Mohanty PK, Chattopadhyay S, Chakraborty NG, et al. Mammalian non-classical major histocompatibility complex I and its receptors: important contexts of gene, evolution, and immunity. Indian J Hum Genet (2014) 20:129-41. doi:10.4103/09716866.142855

40. Nomura T, Huang W-C, Zhau HE, Josson S, Mimata H, Chung LWK. $\beta 2$ Microglobulin-mediated signaling as a target for cancer therapy. Anticancer Agents Med Chem (2014) 14:343-52. doi:10.2174/18715206113139990092

41. Stapleton NM, Einarsdóttir HK, Stemerding AM, Vidarsson G. The multiple facets of FcRn in immunity. Immunol Rev (2015) 268:253-68. doi:10.1111/ imr. 12331

42. Martins JP, Kennedy PJ, Santos HA, Barrias C, Sarmento B. A comprehensive review of the neonatal $\mathrm{Fc}$ receptor and its application in drug delivery. Pharmacol Ther (2016) 161:22-39. doi:10.1016/j.pharmthera.2016.03.007 
43. Simister NE, Mostov KE. An Fc receptor structurally related to MHC class I antigens. Nature (1989) 337:184-7. doi:10.1038/337184a0

44. Israel EJ, Patel VK, Taylor SF, Marshak-Rothstein A, Simister NE. Requirement for a beta 2-microglobulin-associated $\mathrm{Fc}$ receptor for acquisition of maternal IgG by fetal and neonatal mice. J Immunol (1995) 154:6246-51.

45. Junghans RP, Anderson CL. The protection receptor for IgG catabolism is the beta2-microglobulin-containing neonatal intestinal transport receptor. Proc Natl Acad Sci U S A (1996) 93:5512-6. doi:10.1073/pnas.93.11.5512

46. Berryman M, Rodewald R. Beta 2-microglobulin co-distributes with the heavy chain of the intestinal IgG-Fc receptor throughout the transepithelial transport pathway of the neonatal rat. J Cell Sci (1995) 108:2347-60.

47. Ghetie V, Hubbard JG, Kim JK, Tsen MF, Lee Y, Ward ES. Abnormally short serum half-lives of IgG in beta 2-microglobulin-deficient mice. Eur J Immunol (1996) 26:690-6. doi:10.1002/eji.1830260327

48. Zhu X, Peng J, Raychowdhury R, Nakajima A, Lencer WI, Blumberg RS. The heavy chain of neonatal Fc receptor for IgG is sequestered in endoplasmic reticulum by forming oligomers in the absence of $\beta 2$-microglobulin association. Biochem J (2002) 367:703-14. doi:10.1042/bj20020200

49. Kim J, Hayton WL, Robinson JM, Anderson CL. Kinetics of FcRn-mediated recycling of IgG and albumin in human: pathophysiology and therapeutic implications using a simplified mechanism-based model. Clin Immunol (2007) 122:146-55. doi:10.1016/j.clim.2006.09.001

50. Akilesh S, Huber TB, Wu H, Wang G, Hartleben B, Kopp JB, et al. Podocytes use FcRn to clear IgG from the glomerular basement membrane. Proc Natl Acad Sci U S A (2008) 105:967-72. doi:10.1073/pnas.0711515105

51. Dobrinskikh E, Okamura K, Kopp JB, Doctor RB, Blaine J. Human podocytes perform polarized, caveolae-dependent albumin endocytosis. Am J Physiol Renal Physiol (2014) 306:F941-51. doi:10.1152/ajprenal.00532.2013

52. Tenten V, Menzel S, Kunter U, Sicking E-M, van Roeyen CRC, Sanden SK, et al. Albumin is recycled from the primary urine by tubular transcytosis. J Am Soc Nephrol (2013) 24:1966-80. doi:10.1681/ASN.2013010018

53. Sarav M, Wang Y, Hack BK, Chang A, Jensen M, Bao L, et al. Renal FcRn reclaims albumin but facilitates elimination of IgG. J Am Soc Nephrol (2009) 20:1941-52. doi:10.1681/ASN.2008090976

54. Gan H, Feng S, Wu H, Sun Y, Hu R, Zhao Z, et al. Neonatal Fc receptor stimulation induces ubiquitin c-terminal hydrolase-1 overexpression in podocytes through activation of p38 mitogen-activated protein kinase. Hum Pathol (2012) 43:1482-90. doi:10.1016/j.humpath.2011.10.025

55. Kang S-W, Natarajan R, Shahed A, Nast CC, LaPage J, Mundel P, et al. Role of 12-lipoxygenase in the stimulation of p38 mitogen-activated protein kinase and collagen $\alpha 5(\mathrm{IV})$ in experimental diabetic nephropathy and in glucose-stimulated podocytes. JAm Soc Nephrol (2003) 14:3178-87. doi:10.1097/01.ASN.0000099702.16315.DE

56. Koshikawa M, Mukoyama M, Mori K, Suganami T, Sawai K, Yoshioka T, et al. Role of p38 mitogen-activated protein kinase activation in podocyte injury and proteinuria in experimental nephrotic syndrome. J Am Soc Nephrol (2005) 16:2690-701. doi:10.1681/ASN.2004121084

57. Kavvadas P, Weis L, Abed AB, Feldman DL, Dussaule J-C, Chatziantoniou C. Renin inhibition reverses renal disease in transgenic mice by shifting the balance between profibrotic and antifibrotic agentsnovelty and significance. Hypertension (2013) 61:901-7. doi:10.1161/HYPERTENSIONAHA.111.00639

58. Kato Y, Mori K, Kasahara M, Osaki K, Ishii A, Mori KP, et al. Natriuretic peptide receptor guanylyl cyclase-A pathway counteracts glomerular injury evoked by aldosterone through $\mathrm{p} 38$ mitogen-activated protein kinase inhibition. Sci Rep (2017) 7:46624. doi:10.1038/srep46624

59. Abbate M, Zoja C, Remuzzi G. How does proteinuria cause progressive renal damage? J Am Soc Nephrol (2006) 17:2974-84. doi:10.1681/ASN.2006040377

60. Ruggenenti P, Cravedi P, Remuzzi G. Mechanisms and treatment of CKD. J Am Soc Nephrol (2012) 23:1917-28. doi:10.1681/ASN.2012040390

61. Ruggenenti P, Fassi A, Ilieva AP, Bruno S, Iliev IP, Brusegan V, et al. Preventing microalbuminuria in type 2 diabetes. N Engl J Med (2004) 351:1941-51. doi:10.1056/NEJMoa042167

62. Okamura K, Dummer P, Kopp J, Qiu L, Levi M, Faubel S, et al. Endocytosis of albumin by podocytes elicits an inflammatory response and induces apoptotic cell death. PLoS One (2013) 8:e54817. doi:10.1371/journal.pone.0054817

63. Sedeek M, Nasrallah R, Touyz RM, Hébert RL. NADPH oxidases, reactive oxygen species, and the kidney: friend and foe. JAm Soc Nephrol (2013) 24:1512-8. doi:10.1681/ASN.2012111112
64. Wan C, Su H, Zhang C. Role of NADPH oxidase in metabolic diseaserelated renal injury: an update. Oxid Med Cell Longev (2016) 2016:e7813072. doi:10.1155/2016/7813072

65. Maekawa H, Inagi R. Stress signal network between hypoxia and ER stress in chronic kidney disease. Front Physiol (2017) 8:74. doi:10.3389/ fphys.2017.00074

66. Small DM, Coombes JS, Bennett N, Johnson DW, Gobe GC. Oxidative stress, anti-oxidant therapies and chronic kidney disease. Nephrology (Carlton) (2012) 17:311-21. doi:10.1111/j.1440-1797.2012.01572.x

67. Jun M, Venkataraman V, Razavian M, Cooper B, Zoungas S, Ninomiya T, et al. Antioxidants for chronic kidney disease. Cochrane Database Syst Rev (2012) (10):CD008176. doi:10.1002/14651858.CD008176.pub2

68. Cao W, Zhou QG, Nie J, Wang GB, Liu Y, Zhou ZM, et al. Albumin overload activates intrarenal renin-angiotensin system through protein kinase $\mathrm{C}$ and NADPH oxidase-dependent pathway. J Hypertens (2011) 29:1411-21. doi:10.1097/HJH.0b013e32834786f0

69. Kinugasa S, Tojo A, Sakai T, Tsumura H, Takahashi M, Hirata Y, et al. Selective albuminuria via podocyte albumin transport in puromycin nephrotic rats is attenuated by an inhibitor of NADPH oxidase. Kidney Int (2011) 80:1328-38. doi:10.1038/ki.2011.282

70. Kang JH, Baik HW, Yoo S-M, Kim JH, Cheong HI, Park C-G, et al. Aliskiren regulates neonatal $\mathrm{Fc}$ receptor and $\mathrm{IgG}$ metabolism with attenuation of anti-GBM glomerulonephritis in mice. Nephron (2016) 134:272-82. doi:10.1159/000448789

71. Olaru F, Luo W, Suleiman H, John PLS, Ge L, Mezo AR, et al. Neonatal Fc receptor promotes immune complex-mediated glomerular disease. J Am Soc Nephrol (2014) 25:918-25. doi:10.1681/ASN.2013050498

72. Ichinose K, Ushigusa T, Nishino A, Nakashima Y, Suzuki T, Horai Y, et al. Lupus nephritis IgG induction of calcium/calmodulin-dependent protein kinase IV expression in podocytes and alteration of their function. Arthritis Rheumatol (2016) 68:944-52. doi:10.1002/art.39499

73. Amsellem S, Gburek J, Hamard G, Nielsen R, Willnow TE, Devuyst O, et al. Cubilin is essential for albumin reabsorption in the renal proximal tubule. J Am Soc Nephrol (2010) 21:1859-67. doi:10.1681/ASN.2010050492

74. Bern M, Sand KMK, Nilsen J, Sandlie I, Andersen JT. The role of albumin receptors in regulation of albumin homeostasis: implications for drug delivery. J Control Release (2015) 211:144-62. doi:10.1016/j.jconrel.2015.06.006

75. Dickson LE, Wagner MC, Sandoval RM, Molitoris BA. The proximal tubule and albuminuria: really! J Am Soc Nephrol (2014) 25:443-53. doi:10.1681/ ASN.2013090950

76. Waldmann TA. Disorders of immunoglobulin metabolism. N Engl JMed (1969) 281:1170-7. doi:10.1056/NEJM196911202812107

77. Waldmann TA, Terry WD. Familial hypercatabolic hypoproteinemia. A disorder of endogenous catabolism of albumin and immunoglobulin. J Clin Invest (1990) 86:2093-8. doi:10.1172/JCI114947

78. Ardeniz Ö, Unger S, Onay H, Ammann S, Keck C, Cianga C, et al. $\beta 2$ microglobulin deficiency causes a complex immunodeficiency of the innate and adaptive immune system. J Allergy Clin Immunol (2015) 136:392-401. doi:10.1016/j.jaci.2014.12.1937

79. Wani MA, Haynes LD, Kim J, Bronson CL, Chaudhury C, Mohanty S, et al. Familial hypercatabolic hypoproteinemia caused by deficiency of the neonatal Fc receptor, FcRn, due to a mutant beta2-microglobulin gene. Proc Natl Acad Sci U S A (2006) 103:5084-9. doi:10.1073/pnas.0600548103

80. de Sousa M, Reimão R, Lacerda R, Hugo P, Kaufmann SH, Porto G. Iron overload in beta 2-microglobulin-deficient mice. Immunol Lett (1994) 39:105-11. doi:10.1016/0165-2478(94)90094-9

81. Pietrangelo A. Hereditary hemochromatosis: pathogenesis, diagnosis, and treatment. Gastroenterology (2010) 139:.e1-2. doi:10.1053/j.gastro.2010.06.013

82. Orr MT, Lanier LL. Natural killer cell education and tolerance. Cell (2010) 142:847-56. doi:10.1016/j.cell.2010.08.031

83. Santos M, Schilham MW, Rademakers LH, Marx JJ, de Sousa M, Clevers H. Defective iron homeostasis in beta 2-microglobulin knockout mice recapitulates hereditary hemochromatosis in man. J Exp Med (1996) 184:1975-85. doi:10.1084/jem.184.5.1975

84. Spriggs MK, Koller BH, Sato T, Morrissey PJ, Fanslow WC, Smithies O, et al. Beta 2-microglobulin-, CD8+ T-cell-deficient mice survive inoculation with high doses of vaccinia virus and exhibit altered IgG responses. Proc Natl Acad Sci U S A (1992) 89:6070-4. doi:10.1073/pnas.89.13.6070 
85. Kim J, Bronson CL, Wani MA, Oberyszyn TM, Mohanty S, Chaudhury C, et al. Beta 2-microglobulin deficient mice catabolize IgG more rapidly than FcRn- alpha-chain deficient mice. Exp Biol Med (Maywood) (2008) 233: 603-9. doi:10.3181/0710-RM-270

86. Schaible UE, Collins HL, Priem F, Kaufmann SHE. Correction of the iron overload defect in beta-2-microglobulin knockout mice by lactoferrin abolishes their increased susceptibility to tuberculosis. J Exp Med (2002) 196:1507-13. doi:10.1084/jem.20020897

87. Rodrigues P, Lopes C, Mascarenhas C, Arosio P, Porto G, De Sousa M. Comparative study between $\mathrm{Hfe}-/$ - and beta2m-/- mice: progression with age of iron status and liver pathology. Int J Exp Pathol (2006) 87:317-24. doi:10.1111/j.1365-2613.2006.00491.x

88. Muckenthaler MU, Rodrigues P, Macedo MG, Minana B, Brennan $\mathrm{K}$, Cardoso EM, et al. Molecular analysis of iron overload in beta2microglobulin-deficient mice. Blood Cells Mol Dis (2004) 33:125-31. doi:10.1016/j.bcmd.2004.05.003

89. Miranda CJ, Makui H, Andrews NC, Santos MM. Contributions of $\beta 2$ microglobulin-dependent molecules and lymphocytes to iron regulation: insights from HfeRag1-/- and $\beta 2 \mathrm{mRag} 1-/-$ double knock-out mice. Blood (2004) 103:2847-9. doi:10.1182/blood-2003-09-3300

90. Klingel K, Schnorr J-J, Sauter M, Szalay G, Kandolf R. beta2-microglobulinassociated regulation of interferon-gamma and virus-specific immunoglobulin G confer resistance against the development of chronic coxsackievirus myocarditis. Am J Pathol (2003) 162:1709-20. doi:10.1016/ S0002-9440(10)64305-2

91. Sherwood ER, Lin CY, Tao W, Hartmann CA, Dujon JE, French AJ, et al. \{beta\} 2 microglobulin knockout mice are resistant to lethal intraabdominal sepsis. Am J Respir Crit Care Med (2003) 167:1641-9. doi:10.1164/ rccm.200208-950OC

92. Vikingsson A, Pederson K, Muller D. Altered kinetics of CD4+ T cell proliferation and interferon-gamma production in the absence of CD8+ $\mathrm{T}$ lymphocytes in virus-infected beta2-microglobulin-deficient mice. Cell Immunol (1996) 173:261-8. doi:10.1006/cimm.1996.0276

93. Tarleton RL, Koller BH, Latour A, Postan M. Susceptibility of beta 2-microglobulin-deficient mice to Trypanosoma cruzi infection. Nature (1992) 356:338-40. doi:10.1038/356338a0

94. D’Souza CD, Cooper AM, Frank AA, Ehlers S, Turner J, Bendelac A, et al. A novel nonclassic beta2-microglobulin-restricted mechanism influencing early lymphocyte accumulation and subsequent resistance to tuberculosis in the lung. Am J Respir Cell Mol Biol (2000) 23:188-93. doi:10.1165/ ajrcmb.23.2.4063

95. Flynn JL, Goldstein MM, Triebold KJ, Koller B, Bloom BR. Major histocompatibility complex class I-restricted $\mathrm{T}$ cells are required for resistance to Mycobacterium tuberculosis infection. Proc Natl Acad Sci U S A (1992) 89:12013-7. doi:10.1073/pnas.89.24.12013

96. Hildeman D, Salvato M, Whitton JL, Muller D. Vaccination protects beta 2 microglobulin deficient mice from immune mediated mortality but not from persisting viral infection. Vaccine (1996) 14:1223-9. doi:10.1016/ S0264-410X(96)00028-X

97. Cogen AL, Moore TA. Beta2-microglobulin-dependent bacterial clearance and survival during murine Klebsiella pneumoniae bacteremia. Infect Immun (2009) 77:360-6. doi:10.1128/IAI.00909-08

98. Ladel CH, Flesch IE, Arnoldi J, Kaufmann SH. Studies with MHC-deficient knock-out mice reveal impact of both MHC I- and MHC II-dependent T cell responses on Listeria monocytogenes infection. J Immunol (1994) 153:3116-22.

99. Tarakanova VL, Suarez F, Tibbetts SA, Jacoby MA, Weck KE, Hess JL, et al. Murine gammaherpesvirus 68 infection is associated with lymphoproliferative disease and lymphoma in BALB beta2 microglobulin-deficient mice. J Virol (2005) 79:14668-79. doi:10.1128/JVI.79.23.14668-14679.2005

100. Drake DR, Lukacher AE. Beta 2-microglobulin knockout mice are highly susceptible to polyoma virus tumorigenesis. Virology (1998) 252:275-84. doi:10.1006/viro.1998.9455

101. Mozes E, Kohn LD, Hakim F, Singer DS. Resistance of MHC class I-deficient mice to experimental systemic lupus erythematosus. Science (1993) 261:91-3. doi:10.1126/science. 8316860

102. Mixter PF, Russell JQ, Durie FH, Budd RC. Decreased CD4-CD8- TCR-alpha beta + cells in lpr/lpr mice lacking beta 2 -microglobulin. J Immunol (1995) 154:2063-74.
103. Chan OT, Paliwal V, McNiff JM, Park SH, Bendelac A, Shlomchik MJ. Deficiency in beta(2)-microglobulin, but not CD1, accelerates spontaneous lupus skin disease while inhibiting nephritis in MRL-Fas(lpr) nice: an example of disease regulation at the organ level. J Immunol (2001) 167:2985-90. doi:10.4049/jimmunol.167.5.2985

104. Christianson GJ, Blankenburg RL, Duffy TM, Panka D, Roths JB, Marshak-Rothstein A, et al. beta2-microglobulin dependence of the lupus-like autoimmune syndrome of MRL-lpr mice. J Immunol (1996) 156:4932-9.

105. Tsumiyama K, Hashiramoto A, Takimoto M, Tsuji-Kawahara S, Miyazawa M, Shiozawa S. IFN- $\gamma$-producing effector CD8 T lymphocytes cause immune glomerular injury by recognizing antigen presented as immune complex on target tissue. J Immunol (2013) 191:91-6. doi:10.4049/jimmunol.1203217

106. Barton JC, Edwards CQ, Acton RT. HFE gene: structure, function, mutations, and associated iron abnormalities. Gene (2015) 574:179-92. doi:10.1016/j. gene.2015.10.009

107. Bhatt L, Horgan CP, McCaffrey MW. Knockdown of beta2-microglobulin perturbs the subcellular distribution of HFE and hepcidin. Biochem Biophys Res Commun (2009) 378:727-31. doi:10.1016/j.bbrc.2008.11.118

108. Forman DT. Beta-2 microglobulin - an immunogenetic marker of inflammatory and malignant origin. Ann Clin Lab Sci (1982) 12:447-52.

109. Mayo Medical Laboratories. FB2MU - Overview: Beta-2-Microglobulin, Urine (2017). Available from: http://www.mayomedicallaboratories.com/ test-catalog/Overview/75161

110. Mayo Medical Laboratories. B2M - Overview: Beta-2-Microglobulin (Beta2-M), Serum (2017). Available from: http://www.mayomedicallaboratories. com/test-catalog/Overview/9234

111. Diamondstone LS, Tollerud DJ, Fuchs D, Wachter H, Brown LM, Maloney E, et al. Factors influencing serum neopterin and beta 2-microglobulin levels in a healthy diverse population. J Clin Immunol (1994) 14:368-74. doi:10.1007/ BF01546321

112. Juraschek SP, Coresh J, Inker LA, Levey AS, Köttgen A, Foster MC, et al. Comparison of serum concentrations of $\beta$-trace protein, $\beta 2$-microglobulin, cystatin C, and creatinine in the US population. Clin J Am Soc Nephrol (2013) 8:584-92. doi:10.2215/CJN.08700812

113. Swanson RA, Tracy RP, Katzmann JA, Wilson DM, Young DS. Beta 2-microglobulin determined by radioimmunoassay with monoclonal antibody. Clin Chem (1982) 28:2033-9.

114. Aulitzky WE, Grosse-Wilde H, Westhoff U, Tilg H, Aulitzky W, Gastl G, et al. Enhanced serum levels of soluble HLA class I molecules are induced by treatment with recombinant interferon-gamma (IFN-gamma). Clin Exp Immunol (1991) 86:236-9. doi:10.1111/j.1365-2249.1991.tb05802.x

115. Nachbaur K, Troppmair J, Bieling P, Kotlan B, König P, Huber C. Cytokines in the control of beta-2 microglobulin release. I. In vitro studies on various haemopoietic cells. Immunobiology (1988) 177:55-65. doi:10.1016/ S0171-2985(88)80092-5

116. Nachbaur K, Troppmair J, Kotlan B, König P, Aulitzky W, Bieling P, et al. Cytokines in the control of beta- 2 microglobulin release. II. In vivo studies with recombinant interferons and antigens. Immunobiology (1988) 177:66-75. doi:10.1016/S0171-2985(88)80092-5

117. Roumelioti ME, Nolin T, Unruh ML, Argyropoulos C. Revisiting the middle molecule hypothesis of uremic toxicity: a systematic review of beta 2 microglobulin population kinetics and large scale modeling of hemodialysis trials in silico. PLoS One (2016) 11:e0153157. doi:10.1371/ journal.pone.0153157

118. Gooptu M, Staros E. Beta2-Microglobulin: Reference Range, Interpretation, Collection and Panels (2016). Available from: http://emedicine.medscape. com/article/2086864-overview?pa=WQUfwdeUR9XVfjtQ2OZYGA496bSjaFuljwC25mpHSzFLBWwCtyhZPKTpV4\%2BNyePC8SIvl8zjYv73GUyW5rsbWA\%3D\%3D

119. Daya NR, Voskertchian A, Schneider ALC, Ballew S, McAdams DeMarco M, Coresh J, et al. Kidney function and fracture risk: the atherosclerosis risk in communities (ARIC) study. Am J Kidney Dis (2016) 67:218-26. doi:10.1053/j. ajkd.2015.06.020

120. Vincent C, Pozet N, Revillard JP. Plasma beta 2 microglobulin turnover in renal insufficiency. Acta Clin Belg Suppl (1980) 35:2-12. doi:10.1080/22953 337.1980.11718773

121. Wibell L, Evrin PE, Berggård I. Serum 2 -microglobulin in renal disease. Nephron (1973) 10:320-31. doi:10.1159/000180203 
122. Shea PH, Maher JF, Horak E. Prediction of glomerular filtration rate by serum creatinine and beta 2-microglobulin. Nephron (1981) 29:30-5. doi:10.1159/000182234

123. Inker LA, Tighiouart $\mathrm{H}$, Coresh J, Foster MC, Anderson AH, Beck GJ, et al. GFR estimation using $\beta$-trace protein and $\beta 2$-microglobulin in CKD. Am J Kidney Dis (2016) 67:40-8. doi:10.1053/j.ajkd.2015.07.025

124. Aparicio SA, Mojiminiyi S, Kay JD, Shepstone BJ, de Ceulaer K, Serjeant GR. Measurement of glomerular filtration rate in homozygous sickle cell disease: a comparison of 51Cr-EDTA clearance, creatinine clearance, serum creatinine and beta 2 microglobulin. J Clin Pathol (1990) 43:370-2. doi:10.1136/ jcp.43.5.370

125. Yun J-P, Suh C, Lee E, Chang JW, Yang WS, Park JS, et al. Comparison of serum beta 2 -microglobulin and 24 hour urinary creatinine clearance as a prognostic factor in multiple myeloma. J Korean Med Sci (2006) 21:639-44. doi:10.3346/jkms.2006.21.4.639

126. Jovanović D, Krstivojević P, Obradović I, Durdević V, Dukanović L. Serum cystatin $\mathrm{C}$ and beta2-microglobulin as markers of glomerular filtration rate. Ren Fail (2003) 25:123-33. doi:10.1081/JDI-120017475

127. Aksun SA, Ozmen D, Ozmen B, Parildar Z, Mutaf I, Turgan N, et al. Beta2-microglobulin and cystatin $\mathrm{C}$ in type 2 diabetes: assessment of diabetic nephropathy. Exp Clin Endocrinol Diabetes (2004) 112:195-200. doi:10.1055/s-2004-817933

128. Bianchi C, Donadio C, Tramonti G, Consani C, Lorusso P, Rossi G. Reappraisal of serum beta2-microglobulin as marker of GFR. Ren Fail (2001) 23:419-29. doi:10.1081/JDI-100104725

129. Donadio C, Lucchesi A, Ardini M, Giordani R. Cystatin C, beta 2microglobulin, and retinol-binding protein as indicators of glomerular filtration rate: comparison with plasma creatinine. J Pharm Biomed Anal (2001) 24:835-42. doi:10.1016/S0731-7085(00)00550-1

130. Donadio C, Lucchesi A, Ardini M, Donadio E, Giordani R. Serum levels of beta-trace protein and glomerular filtration rate - preliminary results. J Pharm Biomed Anal (2003) 32:1099-104. doi:10.1016/S0731-7085(03)00215-2

131. Fry AC, Singh DK, Chandna SM, Farrington K. Relative importance of residual renal function and convection in determining beta-2-microglobulin levels in high-flux haemodialysis and on-line haemodiafiltration. Blood Purif (2007) 25:295-302. doi:10.1159/000104870

132. Vilar E, Boltiador C, Wong J, Viljoen A, Machado A, Uthayakumar A, et al. Plasma levels of middle molecules to estimate residual kidney function in haemodialysis without urine collection. PLoS One (2015) 10:e0143813. doi:10.1371/journal.pone.0143813

133. Liu X, Foster MC, Tighiouart H, Anderson AH, Beck GJ, Contreras G, et al. Non-GFR determinants of low-molecular-weight serum protein filtration markers in CKD. Am J Kidney Dis (2016) 68:892-900. doi:10.1053/j. ajkd.2016.07.021

134. Parikh CR, Koyner JL. Biomarkers in acute and chronic kidney diseases. Brenner and Rector's The Kidney. Elsevier (2015). p. 926-55.

135. Filler G, Witt I, Priem F, Ehrich JHH, Jung K. Are cystatin C and $\beta 2$-microglobulin better markers than serum creatinine for prediction of a normal glomerular filtration rate in pediatric subjects? Clin Chem (1997) 43:1077-8.

136. Ikezumi Y, Honda M, Matsuyama T, Ishikura K, Hataya $H$, Yata N, et al. Establishment of a normal reference value for serum $\beta 2$ microglobulin in Japanese children: reevaluation of its clinical usefulness. Clin Exp Nephrol (2013) 17:99-105. doi:10.1007/s10157-012-0658-7

137. Ikezumi Y, Uemura O, Nagai T, Ishikura K, Ito S, Hataya H, et al. Beta-2 microglobulin-based equation for estimating glomerular filtration rates in Japanese children and adolescents. Clin Exp Nephrol (2015) 19:450-7. doi:10.1007/s10157-014-1015-9

138. Filler G, Priem F, Lepage N, Sinha P, Vollmer I, Clark H, et al. Beta-trace protein, cystatin C, beta(2)-microglobulin, and creatinine compared for detecting impaired glomerular filtration rates in children. Clin Chem (2002) 48:729-36.

139. Van Acker KJ, Vlietinck RF, Steels PM. Estimation of glomerular filtration rate from beta 2-microglobulin serum levels in children. Int J Pediatr Nephrol (1984) 5:59-62.

140. Filler G, Alvarez-Elías AC, Westreich KD, Huang S-HS, Lindsay RM. Can the new CKD-EPI BTP-B2M formula be applied in children? Pediatr Nephrol (2016) 31:2175-7. doi:10.1007/s00467-016-3493-3

141. Peterson PA, Evrin P-E, Berggård I. Differentiation of glomerular, tubular, and normal proteinuria: determinations of urinary excretion of $\beta 2$-microglobulin, albumin, and total protein. J Clin Invest (1969) 48:1189-98. doi:10.1172/ JCI106083

142. Portman RJ, Kissane JM, Robson AM. Use of beta 2 microglobulin to diagnose tubulo-interstitial renal lesions in children. Kidney Int (1986) 30:91-8. doi:10.1038/ki.1986.156

143. Christensen EI, Birn H, Storm T, Weyer K, Nielsen R. Endocytic receptors in the renal proximal tubule. Physiology (Bethesda) (2012) 27:223-36. doi:10.1152/physiol.00022.2012

144. Nielsen R, Christensen EI, Birn H. Megalin and cubilin in proximal tubule protein reabsorption: from experimental models to human disease. Kidney Int (2016) 89:58-67. doi:10.1016/j.kint.2015.11.007

145. Orlando RA, Rader K, Authier F, Yamazaki H, Posner BI, Bergeron JJ, et al. Megalin is an endocytic receptor for insulin. J Am Soc Nephrol (1998) 9:1759-66.

146. Leheste J-R, Rolinski B, Vorum H, Hilpert J, Nykjaer A, Jacobsen C, et al. Megalin knockout mice as an animal model of low molecular weight proteinuria. Am J Pathol (1999) 155:1361-70. doi:10.1016/S00029440(10)65238-8

147. Storm T, Tranebjaerg L, Frykholm C, Birn H, Verroust PJ, Nevéus T, et al. Renal phenotypic investigations of megalin-deficient patients: novel insights into tubular proteinuria and albumin filtration. Nephrol Dial Transplant (2013) 28:585-91. doi:10.1093/ndt/gfs462

148. Kantarci S, Al-Gazali L, Hill RS, Donnai D, Black GCM, Bieth E, et al. Mutations in LRP2, which encodes the multiligand receptor megalin, cause Donnai-Barrow and facio-oculo-acoustico-renal syndromes. Nat Genet (2007) 39:957-9. doi:10.1038/ng2063

149. Storm T, Emma F, Verroust PJ, Hertz JM, Nielsen R, Christensen EI. A patient with cubilin deficiency. N Engl J Med (2011) 364:89-91. doi:10.1056/ NEJMc1009804

150. Christensen EI, Birn H. Megalin and cubilin: multifunctional endocytic receptors. Nat Rev Mol Cell Biol (2002) 3:258-68. doi:10.1038/nrm778

151. Sundin DP, Cohen M, Dahl R, Falk S, Molitoris BA. Characterization of the beta 2-microglobulin endocytic pathway in rat proximal tubule cells. Am J Physiol (1994) 267:F380-9.

152. Cohen M, Sundin DP, Dahl R, Molitoris BA. Convergence of apical and basolateral endocytic pathways for beta 2-microglobulin in LLC-PK1 cells. Am J Physiol (1995) 268:F829-38.

153. Kobayashi N, Suzuki Y, Tsuge T, Okumura K, Ra C, Tomino Y. FcRn-mediated transcytosis of immunoglobulin $\mathrm{G}$ in human renal proximal tubular epithelial cells. Am J Physiol Renal Physiol (2002) 282:F358-65. doi:10.1152/ ajprenal.0164.2001

154. Gauthier C, Nguyen-Simonnet H, Vincent C, Revillard JP, Pellet MV. Renal tubular absorption of beta 2 microglobulin. Kidney Int (1984) 26:170-5. doi:10.1038/ki.1984.151

155. Bernard A, Amor AO, Viau C, Lauwerys R. The renal uptake of proteins: a nonselective process in conscious rats. Kidney Int (1988) 34:175-85. doi:10.1038/ki.1988.163

156. Thielemans N, Lauwerys R, Bernard A. Competition between albumin and low-molecular-weight proteins for renal tubular uptake in experimental nephropathies. Nephron (1994) 66:453-8. doi:10.1159/000187863

157. Bernard A, Viau C, Ouled A, Lauwerys R. Competition between low- and high-molecular-weight proteins for renal tubular uptake. Nephron (1987) 45:115-8. doi:10.1159/000184090

158. Thakkar H, Lowe PA, Price CP, Newman DJ. Measurement of the kinetics of protein uptake by proximal tubular cells using an optical biosensor. Kidney Int (1998) 54:1197-205. doi:10.1046/j.1523-1755.1998.00098.x

159. Karlsson FA, Hardell LI, Hellsing K. A prospective study of urinary proteins in early infancy. Acta Paediatr Scand (1979) 68:663-7. doi:10.1111/j. 1651-2227.1979.tb18435.x

160. Dieterle F, Perentes E, Cordier A, Roth DR, Verdes P, Grenet O, et al. Urinary clusterin, cystatin C, $\beta 2$-microglobulin and total protein as markers to detect drug-induced kidney injury. Nat Biotechnol (2010) 28:463-9. doi:10.1038/ nbt. 1622

161. Kuwata K, Nakamura I, Ide M, Sato H, Nishikawa S, Tanaka M. Comparison of changes in urinary and blood levels of biomarkers associated with proximal tubular injury in rat models. J Toxicol Pathol (2015) 28:151-64. doi:10.1293/ tox.2014-0039

162. Vlasakova K, Erdos Z, Troth SP, McNulty K, Chapeau-Campredon V, Mokrzycki N, et al. Evaluation of the relative performance of 12 urinary 
biomarkers for renal safety across 22 rat sensitivity and specificity studies. Toxicol Sci (2014) 138:3-20. doi:10.1093/toxsci/kft330

163. Shin JR, Kim SM, Yoo JS, Park JY, Kim SK, Cho JH, et al. Urinary excretion of $\beta_{2}$-microglobulin as a prognostic marker in immunoglobulin A nephropathy. Korean J Intern Med (2014) 29:334-40. doi:10.3904/ kjim.2014.29.3.334

164. Choe J-Y, Park S-H, Kim S-K. Urine $\beta 2$-microglobulin is associated with clinical disease activity and renal involvement in female patients with systemic lupus erythematosus. Lupus (2014) 23:1486-93. doi:10.1177/0961203314547797

165. Bagshaw SM, Langenberg C, Haase M, Wan L, May CN, Bellomo R. Urinary biomarkers in septic acute kidney injury. Intensive Care Med (2007) 33:1285-96. doi:10.1007/s00134-007-0656-5

166. Zeng X, Hossain D, Bostwick DG, Herrera GA, Zhang PL. Urinary beta2-microglobulin is a good indicator of proximal tubule injury: a correlative study with renal biopsies. J Biomarkers (2014) 2014:e492838. doi: $10.1155 / 2014 / 492838$

167. Kaye WA, Griffiths WC, Camara PD, Trebbin WM, Solomon RJ, Diamond I. The significance of beta-2 microglobulinuria associated with gentamicin therapy. Ann Clin Lab Sci (1981) 11:530-7.

168. Blumsohn A, Morris BW, Griffiths H, Ramsey CF. Stability of beta 2microglobulin and retinol binding protein at different values of $\mathrm{pH}$ and temperature in normal and pathological urine. Clin Chim Acta (1991) 195:133-7. doi:10.1016/0009-8981(91)90133-W

169. Donaldson MD, Chambers RE, Woolridge MW, Whicher JT. Stability of alpha 1-microglobulin, beta 2-microglobulin and retinol binding protein in urine. Clin Chim Acta (1989) 179:73-7. doi:10.1016/0009-8981(89)90024-7

170. Bastable MD. Beta 2 microglobulin in urine: not suitable for assessing renal tubular function. Clin Chem (1983) 29:996-7.

171. Bernard AM, Vyskocil AA, Mahieu P, Lauwerys RR. Assessment of urinary retinol-binding protein as an index of proximal tubular injury. Clin Chem (1987) 33:775-9.

172. Hu J, Li M, Han T, Chen J, Ye L, Wang Q, et al. Benchmark dose estimation for cadmium-induced renal tubular damage among environmental cadmiumexposed women aged 35-54 years in two counties of China. PLoS One (2014) 9:e115794. doi:10.1371/journal.pone.0115794

173. Ke S, Cheng X-Y, Zhang J-Y, Jia W-J, Li H, Luo H-F, et al. Estimation of the benchmark dose of urinary cadmium as the reference level for renal dysfunction: a large sample study in five cadmium polluted areas in China. BMC Public Health (2015) 15:656. doi:10.1186/s12889-015-2021-x

174. Kim Y-D, Yim D-H, Eom S-Y, Moon S-I, Park C-H, Kim G-B, et al. Temporal changes in urinary levels of cadmium, $\mathrm{N}$-acetyl- $\beta$-D-glucosaminidase and $\beta 2$-microglobulin in individuals in a cadmium-contaminated area. Environ Toxicol Pharmacol (2015) 39:35-41. doi:10.1016/j.etap.2014.10.016

175. Nishijo M, Suwazono Y, Ruangyuttikarn W, Nambunmee K, Swaddiwudhipong W, Nogawa K, et al. Risk assessment for Thai population: benchmark dose of urinary and blood cadmium levels for renal effects by hybrid approach of inhabitants living in polluted and non-polluted areas in Thailand. BMC Public Health (2014) 14:702. doi:10.1186/1471-2458-14-702

176. Rybakowski JK, Abramowicz M, Chłopocka-Wozniak M, Czekalski S. Novel markers of kidney injury in bipolar patients on long-term lithium treatment. Hum Psychopharmacol (2013) 28:615-8. doi:10.1002/hup.2362

177. Nishijima T, Gatanaga H, Komatsu H, Tsukada K, Shimbo T, Aoki T, et al. Renal function declines more in tenofovir- than abacavir-based antiretroviral therapy in low-body weight treatment-naive patients with HIV infection. PLoS One (2012) 7:e29977. doi:10.1371/journal.pone.0029977

178. Oboho I, Abraham A, Benning L, Anastos K, Sharma A, Young M, et al. Tenofovir use and urinary biomarkers among HIV-infected women in the Women's Interagency HIV Study (WIHS). J Acquir Immune Defic Syndr (2013) 62:388-95. doi:10.1097/QAI.0b013e31828175c9

179. Gatanaga H, Tachikawa N, Kikuchi Y, Teruya K, Genka I, Honda M, et al. Urinary beta2-microglobulin as a possible sensitive marker for renal injury caused by tenofovir disoproxil fumarate. AIDS Res Hum Retroviruses (2006) 22:744-8. doi:10.1089/aid.2006.22.744

180. Joyce E, Glasner P, Ranganathan S, Swiatecka-Urban A. Tubulointerstitial nephritis: diagnosis, treatment, and monitoring. Pediatr Nephrol (2017) 32:577-87. doi:10.1007/s00467-016-3394-5

181. Tomlinson PA, Dalton RN, Hartley B, Haycock GB, Chantler C. Low molecular weight protein excretion in glomerular disease: a comparative analysis. Pediatr Nephrol (1997) 11:285-90. doi:10.1007/s004670050278
182. Hettinga YM, Scheerlinck LME, Lilien MR, Rothova A, de Boer JH. The value of measuring urinary $\beta 2$-microglobulin and serum creatinine for detecting tubulointerstitial nephritis and uveitis syndrome in young patients with uveitis. JAMA Ophthalmol (2015) 133:140-5. doi:10.1001/ jamaophthalmol.2014.4301

183. Badr M, El Koumi MA, Ali YF, El-Morshedy S, Almonem NA, Hassan T, et al. Renal tubular dysfunction in children with sickle cell haemoglobinopathy. Nephrology (Carlton) (2013) 18:299-303. doi:10.1111/nep.12040

184. Unal S, Kotan C, Delibas A, Oztas Y, Cystatin C. Beta2 microglobulin, $\mathrm{N}$-acetyl-beta-D-glucosaminidase, retinol-binding protein, and endothelin 1 levels in the evaluation of sickle cell disease nephropathy. Pediatr Hematol Oncol (2015) 32:250-7. doi:10.3109/08880018.2013.810317

185. Stefanowicz J, Owczuk R, Aleksandrowicz E, Owczarzak A, Kurylak A, Adamkiewicz-Drożyńska E, et al. Renal function and low-molecular-weight proteins (cystatin C, $\beta 2$-microglobulin, neutrophil gelatinase-associated lipocalin) in child and young adult cancer survivors. J Pediatr Hematol Oncol (2012) 34:461-6. doi:10.1097/MPH.0b013e318257fd89

186. Fang J, Luan J, Zhu G, Qi C, Wang D. Detection of PCT and urinary $\beta 2$-MG enhances the accuracy for localization diagnosing pediatric urinary tract infection. J Clin Lab Anal (2016). doi:10.1002/jcla.22088

187. Korpal-Szczyrska N, Uszycia-Karcz M, Mierzewski P. Urinary excretion of beta-2-microglobulin in children with urinary tract infections. Pediatr Res (1989) 26:505-505. doi:10.1203/00006450-198911000-00035

188. Salvaggio E, Menonna NM, Ricci R, Ferrara P, Nardini F. [Beta 2 microglobulin in the diagnosis of reflux nephropathy in childhood]. Pediatr Med Chir (1988) 10:83-8.

189. Madsen MG, Nørregaard R, Palmfeldt J, Olsen LH, Frøkiaer J, Jørgensen TM. Urinary NGAL, cystatin C, $\beta 2$-microglobulin, and osteopontin significance in hydronephrotic children. Pediatr Nephrol (2012) 27:2099-106. doi:10.1007/ s00467-012-2217-6

190. El-Frargy MS, El-Refaey AM, Eid R, Hussien MA. Serum cystatin-C and BETA 2-microglobulin as accurate markers in the early diagnosis of kidney injury in neonates: a single center study. Saudi J Kidney Dis Transpl (2015) 26:712-7. doi:10.4103/1319-2442.160151

191. Herrero-Morín JD, Málaga S, Fernández N, Rey C, Diéguez MA, Solís G, et al. Cystatin $\mathrm{C}$ and beta2-microglobulin: markers of glomerular filtration in critically ill children. Crit Care (2007) 11:R59. doi:10.1186/cc5923

192. Du Y, Zappitelli M, Mian A, Bennett M, Ma Q, Devarajan P, et al. Urinary biomarkers to detect acute kidney injury in the pediatric emergency center. Pediatr Nephrol (2011) 26:267-74. doi:10.1007/s00467-010-1673-0

193. Askenazi DJ, Koralkar R, Levitan EB, Goldstein SL, Devarajan P, Khandrika $S$, et al. Baseline values of candidate urine acute kidney injury biomarkers vary by gestational age in premature infants. Pediatr Res (2011) 70:302-6. doi:10.1203/PDR.0b013e3182275164

194. DeFreitas MJ, Seeherunvong W, Katsoufis CP, RamachandraRao S, Duara S, Yasin S, et al. Longitudinal patterns of urine biomarkers in infants across gestational ages. Pediatr Nephrol (2016) 31:1179-88. doi:10.1007/s00467016-3327-3

195. Liabeuf S, Lenglet A, Desjardins L, Neirynck N, Glorieux G, Lemke HD, et al. Plasma beta-2 microglobulin is associated with cardiovascular disease in uremic patients. Kidney Int (2012) 82:1297-303. doi:10.1038/ ki.2012.301

196. Foster MC, Coresh J, Hsu C-Y, Xie D, Levey AS, Nelson RG, et al. Serum $\beta$-trace protein and $\beta 2$-microglobulin as predictors of ESRD, mortality, and cardiovascular disease in adults with CKD in the chronic renal insufficiency cohort (CRIC) study. Am J Kidney Dis (2016) 68(1):68-76. doi:10.1053/j. ajkd.2016.01.015

197. Foster MC, Inker LA, Hsu C-Y, Eckfeldt JH, Levey AS, Pavkov ME, et al. Filtration markers as predictors of ESRD and mortality in Southwestern American Indians with type 2 diabetes. Am J Kidney Dis (2015) 66:75-83. doi:10.1053/j.ajkd.2015.01.013

198. Wu H-C, Lee L-C, Wang W-J. Associations among serum beta 2 microglobulin, malnutrition, inflammation, and advanced cardiovascular event in patients with chronic kidney disease. J Clin Lab Anal (2017) 31(3):e22056. doi:10.1002/jcla.22056

199. Inker LA, Coresh J, Sang Y, Hsu C-Y, Foster MC, Eckfeldt JH, et al. Filtration markers as predictors of ESRD and mortality: individual participant data meta-analysis. Clin J Am Soc Nephrol (2017) 12:69-78. doi:10.2215/ CJN.03660316 
200. Astor BC, Shafi T, Hoogeveen RC, Matsushita K, Ballantyne CM, Inker LA, et al. Novel markers of kidney function as predictors of ESRD, cardiovascular disease, and mortality in the general population. Am J Kidney Dis (2012) 59:653-62. doi:10.1053/j.ajkd.2011.11.042

201. Suzuki T, Agarwal SK, Deo R, Sotoodehnia N, Grams ME, Selvin E, et al. Kidney function and sudden cardiac death in the community: the Atherosclerosis Risk in Communities (ARIC) Study. Am Heart J (2016) 180:46-53. doi:10.1016/j.ahj.2016.07.004

202. Foster MC, Inker LA, Levey AS, Selvin E, Eckfeldt J, Juraschek SP, et al. Novel filtration markers as predictors of all-cause and cardiovascular mortality in US adults. Am J Kidney Dis (2013) 62(1):42-51. doi:10.1053/j. ajkd.2013.01.016

203. Wong J, Sridharan S, Berdeprado J, Vilar E, Viljoen A, Wellsted D, et al. Predicting residual kidney function in hemodialysis patients using serum $\beta$-trace protein and $\beta 2$-microglobulin. Kidney Int (2016) 89:1090-8. doi:10.1016/j.kint.2015.12.042

204. Scribner BH, Babb AL. Evidence for toxins of "middle" molecular weight. Kidney Int Suppl (1975) 3:349-51.

205. Babb AL, Ahmad S, Bergström J, Scribner BH. The middle molecule hypothesis in perspective. Am J Kidney Dis (1981) 1:46-50. doi:10.1016/ S0272-6386(81)80011-X

206. Leypoldt JK, Holmes CJ, Rutherford P. Clearance of middle molecules during haemodialysis and haemodiafiltration: new insights. Nephrol Dial Transplant (2012) 27:4245-7. doi:10.1093/ndt/gfs475

207. Thomas G, Jaber BL. Innovation in the treatment of uremia: proceedings from the Cleveland clinic workshop: convective therapies for removal of middle molecular weight uremic toxins in end-stage renal disease: a review of the evidence. Semin Dial (2009) 22:610-4. doi:10.1111/j.1525139X.2009.00665.x

208. Panichi V, De Ferrari G, Saffiotti S, Sidoti A, Biagioli M, Bianchi S, et al. Comparison of on-line HDF modes automated TMP control vs. volume control on achieved convective volume and middle molecule clearance. Nephrol Dial Transplant (2012) 27:ii205-6. doi:10.1093/ndt/gfs224

209. Tattersall J. Clearance of beta-2-microglobulin and middle molecules in haemodiafiltration. Contrib Nephrol (2007) 158:201-9. doi:10.1159/000107251

210. Okuno S, Ishimura E, Kohno K, Fujino-Katoh Y, Maeno Y, Yamakawa T, et al. Serum beta2-microglobulin level is a significant predictor of mortality in maintenance haemodialysis patients. Nephrol Dial Transplant (2009) 24:571-7. doi:10.1093/ndt/gfn521

211. Kim KM, Kim S-S, Kim H, Koo T, Im EY, Kim SB. Higher serum beta2-microglobulin levels are associated with better survival in chronic hemodialysis patients: a reverse epidemiology. Clin Nephrol (2011) 75:458-65. doi:10.5414/ CNP75458

212. Carreno MP, Rousseau Y, Poignet JL, Jahns G, Cholley B, Kazatchkine MD, et al. Dissociation between beta-2 microglobulin and IL-1 production in hemodialyzed patients. Nephrol Dial Transplant (1997) 12:2365-74. doi:10.1093/ ndt/12.11.2365

213. Caruana RJ, Lobel SA, Leffell MS, Campbell H, Cheek PL. Tumor necrosis factor, interleukin-1 and beta 2-microglobulin levels in chronic hemodialysis patients. Int J Artif Organs (1990) 13:794-8.

214. Memoli B, Libetta C, Rampino T, Canton AD, Conte G, Scala G, et al. Hemodialysis related induction of interleukin- 6 production by peripheral blood mononuclear cells. Kidney Int (1992) 42:320-6. doi:10.1038/ ki.1992.292

215. Pertosa G, Marfella C, Tarantino EA, Di Cillo M, Manno C, Russo R, et al. Involvement of peripheral blood monocytes in haemodialysis: in vivo induction of tumour necrosis factor alpha, interleukin 6 and beta 2-microglobulin. Nephrol Dial Transplant (1991) 6(Suppl 2):18-23.

216. Akchurin OM, Kaskel F. Update on inflammation in chronic kidney disease. Blood Purif (2015) 39:84-92. doi:10.1159/000368940

217. Topçiu-Shufta V, Miftari R, Haxhibeqiri V, Haxhibeqiri S. Association of beta- 2 microglobulin with inflammation and dislipidemia in high-flux membrane hemodialysis patients. Med Arch (2016) 70:348-50. doi:10.5455/ medarh.2016.70.348-350

218. Lonnemann G, Novick D, Rubinstein M, Passlick-Deetjen J, Lang D, Dinarello CA. A switch to high-flux helixone membranes reverses suppressed interferon-gamma production in patients on low-flux dialysis. Blood Purif (2003) 21:225-31. doi:10.1159/000070694
219. Lonnemann G, Bahlmann FH, Freise J, Hertel B, Dinarello CA. Low-flux hemodialysis suppresses interferon-gamma production: the possible role of beta2-microglobulin. Clin Nephrol (2009) 72:170-6. doi:10.5414/CNP72170

220. Palmer SC, Rabindranath KS, Craig JC, Roderick PJ, Locatelli F, Strippoli GFM. High-flux versus low-flux membranes for end-stage kidney disease. Cochrane Database Syst Rev (2012) (9):CD005016. doi:10.1002/14651858.CD005016.pub2

221. Eknoyan G, Beck GJ, Cheung AK, Daugirdas JT, Greene T, Kusek JW, et al. Effect of dialysis dose and membrane flux in maintenance hemodialysis. $N$ Engl J Med (2002) 347:2010-9. doi:10.1056/NEJMoa021583

222. Cheung AK, Levin NW, Greene T, Agodoa L, Bailey J, Beck G, et al. Effects of high-flux hemodialysis on clinical outcomes: results of the HEMO study. J Am Soc Nephrol (2003) 14:3251-63. doi:10.1097/01.ASN. 0000096373.13406.94

223. Delmez JA, Yan G, Bailey J, Beck GJ, Beddhu S, Cheung AK, et al. Cerebrovascular disease in maintenance hemodialysis patients: results of the HEMO Study. Am J Kidney Dis (2006) 47:131-8. doi:10.1053/j. ajkd.2005.09.031

224. Cheung AK, Rocco MV, Yan G, Leypoldt JK, Levin NW, Greene T, et al. Serum $\beta-2$ microglobulin levels predict mortality in dialysis patients: results of the HEMO study. JAm Soc Nephrol (2006) 17:546-55. doi:10.1681/ ASN.2005020132

225. Cheung AK, Greene T, Leypoldt JK, Yan G, Allon M, Delmez J, et al. Association between serum $\beta 2$-microglobulin level and infectious mortality in hemodialysis patients. Clin J Am Soc Nephrol (2008) 3:69-77. doi:10.2215/ CJN.02340607

226. Locatelli F, Gauly A, Czekalski S, Hannedouche T, Jacobson SH, Loureiro A, et al. The MPO Study: just a European HEMO Study or something very different? Blood Purif (2008) 26:100-4. doi:10.1159/000110574

227. Locatelli F, Martin-Malo A, Hannedouche T, Loureiro A, Papadimitriou M, Wizemann $\mathrm{V}$, et al. Effect of membrane permeability on survival of hemodialysis patients. JAm Soc Nephrol (2009) 20:645-54. doi:10.1681/ASN. 2008060590

228. Locatelli F, Cavalli A, Manzoni C, Pontoriero G. The membrane permeability outcome study. Contrib Nephrol (2011) 175:81-92. doi:10.1159/000333816

229. Argyropoulos C, Roumelioti M-E, Sattar A, Kellum JA, Weissfeld L, Unruh ML. Dialyzer reuse and outcomes of high flux dialysis. PLoS One (2015) 10:e0129575. doi:10.1371/journal.pone.0129575

230. Chazot C, Kirchgessner J, Pham J, Vo-Van C, Lorriaux C, Hurot J-M, et al. Effect of membrane permeability on cardiovascular risk factors and $\beta 2 \mathrm{~m}$ plasma levels in patients on long-term haemodialysis: a randomised crossover trial. Nephron (2015) 129:269-75. doi:10.1159/000380767

231. Locatelli F, Vecchio LD, Milia VL. Haemodiafiltration at higher volumes and patient survival. Contrib Nephrol (2016) 189:1-8. doi:10.1159/000450632

232. Mostovaya IM, Blankestijn PJ, Bots ML, Covic A, Davenport A, Grooteman MPC, et al. Clinical evidence on hemodiafiltration: a systematic review and a meta-analysis. Semin Dial (2014) 27:119-27. doi:10.1111/sdi.12200

233. Nistor I, Palmer SC, Craig JC, Saglimbene V, Vecchio M, Covic A, et al. Convective versus diffusive dialysis therapies for chronic kidney failure: an updated systematic review of randomized controlled trials. Am J Kidney Dis (2014) 63:954-67. doi:10.1053/j.ajkd.2013.12.004

234. Nistor I, Palmer SC, Craig JC, Saglimbene V, Vecchio M, Covic A, et al. Haemodiafiltration, haemofiltration and haemodialysis for end-stage kidney disease. Cochrane Database Syst Rev (2015) (5):CD006258. doi:10.1002/14651858.CD006258.pub2

235. Susantitaphong P, Siribamrungwong M, Jaber BL. Convective therapies versus low-flux hemodialysis for chronic kidney failure: a meta-analysis of randomized controlled trials. Nephrol Dial Transplant (2013) 28:2859-74. doi:10.1093/ndt/gft396

236. Wang AY, Ninomiya T, Al-Kahwa A, Perkovic V, Gallagher MP, Hawley C, et al. Effect of hemodiafiltration or hemofiltration compared with hemodialysis on mortality and cardiovascular disease in chronic kidney failure: a systematic review and meta-analysis of randomized trials. Am J Kidney Dis (2014) 63:968-78. doi:10.1053/j.ajkd.2014.01.435

237. Canaud B, Barbieri C, Marcelli D, Bellocchio F, Bowry S, Mari F, et al. Optimal convection volume for improving patient outcomes in an international incident dialysis cohort treated with online hemodiafiltration. Kidney Int (2015) 88:1108-16. doi:10.1038/ki.2015.139 
238. Canaud B, Bragg-Gresham JL, Marshall MR, Desmeules S, Gillespie BW, Depner T, et al. Mortality risk for patients receiving hemodiafiltration versus hemodialysis: European results from the DOPPS. Kidney Int (2006) 69:2087-93. doi:10.1038/sj.ki.5000447

239. Grooteman MPC, van den Dorpel MA, Bots ML, Penne EL, van der Weerd NC, Mazairac AHA, et al. Effect of online hemodiafiltration on all-cause mortality and cardiovascular outcomes. J Am Soc Nephrol (2012) 23:1087-96. doi:10.1681/ASN.2011121140

240. Ok E, Asci G, Toz H, Ok ES, Kircelli F, Yilmaz M, et al. Mortality and cardiovascular events in online haemodiafiltration (OL-HDF) compared with high-flux dialysis: results from the Turkish OL-HDF Study. Nephrol Dial Transplant (2013) 28:192-202. doi:10.1093/ndt/gfs407

241. Maduell F, Moreso F, Pons M, Ramos R, Mora-Macia J, Carreras J, et al. Highefficiency postdilution online hemodiafiltration reduces all-cause mortality in hemodialysis patients. J Am Soc Nephrol (2013) 24:487-97. doi:10.1681/ ASN.2012080875

242. Peters SAE, Bots ML, Canaud B, Davenport A, Grooteman MPC, Kircelli F, et al. Haemodiafiltration and mortality in end-stage kidney disease patients: a pooled individual participant data analysis from four randomized controlled trials. Nephrol Dial Transplant (2016) 31:978-84. doi:10.1093/ndt/gfv349

243. Santoro A, Mancini E, Bolzani R, Boggi R, Cagnoli L, Francioso A, et al. The effect of on-line high-flux hemofiltration versus low-flux hemodialysis on mortality in chronic kidney failure: a small randomized controlled trial. Am J Kidney Dis (2008) 52:507-18. doi:10.1053/j.ajkd.2008.05.011

244. Koh ES, Lee K, Kim SH, Kim YO, Jin DC, Song HC, et al. Serum $\beta 2-$ microglobulin predicts mortality in peritoneal dialysis patients: a prospective cohort study. Am J Nephrol (2015) 42:91-8. doi:10.1159/000439060

245. Liu X, Dai C. Advances in understanding and management of residual renal function in patients with chronic kidney disease. Kidney Dis (Basel) (2017) 2:187-96. doi:10.1159/000449029

246. Mathew AT, Fishbane S, Obi Y, Kalantar-Zadeh K. Preservation of residual kidney function in hemodialysis patients: reviving an old concept. Kidney Int (2016) 90:262-71. doi:10.1016/j.kint.2016.02.037

247. Termorshuizen F, Korevaar JC, Dekker FW, van Manen JG, Boeschoten EW, Krediet RT, et al. The relative importance of residual renal function compared with peritoneal clearance for patient survival and quality of life: an analysis of the Netherlands Cooperative Study on the Adequacy of Dialysis (NECOSAD)-2. Am J Kidney Dis (2003) 41:1293-302. doi:10.1016/S02726386(03)00362-7

248. Balafa O, Halbesma N, Struijk DG, Dekker FW, Krediet RT. Peritoneal albu$\mathrm{min}$ and protein losses do not predict outcome in peritoneal dialysis patients. Clin J Am Soc Nephrol (2011) 6:561-6. doi:10.2215/CJN.05540610

249. Brimble KS, Walker M, Margetts PJ, Kundhal KK, Rabbat CG. Meta-analysis: peritoneal membrane transport, mortality, and technique failure in peritoneal dialysis. J Am Soc Nephrol (2006) 17:2591-8. doi:10.1681/ASN.2006030194

250. Rajakaruna G, Caplin B, Davenport A. Peritoneal protein clearance rather than faster transport status determines outcomes in peritoneal dialysis patients. Perit Dial Int (2015) 35:216-21. doi:10.3747/pdi.2013.00217

251. Pascual M, Theruvath T, Kawai T, Tolkoff-Rubin N, Cosimi AB. Strategies to improve long-term outcomes after renal transplantation. N Engl J Med (2002) 346:580-90. doi:10.1056/NEJMra011295

252. Heemann U, Lutz J. Pathophysiology and treatment options of chronic renal allograft damage. Nephrol Dial Transplant (2013) 28:2438-46. doi:10.1093/ ndt/gft087

253. Boor P, Floege J. Renal allograft fibrosis: biology and therapeutic targets. Am J Transplant (2015) 15:863-86. doi:10.1111/ajt.13180

254. Bargnoux AS, Servel AC, Piéroni L, Dupuy AM, Badiou S, Garrigue V, et al. Accuracy of GFR predictive equations in renal transplantation: validation of a new turbidimetric cystatin C assay on Architect c8000. Clin Biochem (2012) 45:151-3. doi:10.1016/j.clinbiochem.2011.10.018

255. Buron F, Hadj-Aissa A, Dubourg L, Morelon E, Steghens J-P, Ducher M, et al. Estimating glomerular filtration rate in kidney transplant recipients: performance over time of four creatinine-based formulas. Transplantation (2011) 92:1005-11. doi:10.1097/TP.0b013e3182301602

256. Gourishankar S, Leduc R, Connett J, Cecka JM, Cosio F, Fieberg A, et al. Pathological and clinical characterization of the 'troubled transplant': data from the DeKAF Study. Am J Transplant (2010) 10:324-30. doi:10.1111/j. $1600-6143.2009 .02954 . x$
257. Mannon RB, Kirk AD. Beyond histology: novel tools to diagnose allograft dysfunction. Clin JAm Soc Nephrol (2006) 1:358-66. doi:10.2215/CJN. 01681105

258. Foster MC, Weiner DE, Bostom AG, Carpenter MA, Inker LA, Jarolim P, et al. Filtration markers, cardiovascular disease, mortality, and kidney outcomes in stable kidney transplant recipients: the FAVORIT trial. Am J Transplant (2017). doi:10.1111/ajt.14258

259. Trailin AV, Pleten MV, Ostapenko TI, Iefimenko NF, Nikonenko OS. High serum level of $\beta 2$-microglobulin in late posttransplant period predicts subsequent decline in kidney allograft function: a preliminary study. Dis Markers (2015) 2015:562580. doi:10.1155/2015/562580

260. Michel K, Santella R, Steers J, Sahajpal A, Downey FX, Thohan V, et al. Many de novo donor-specific antibodies recognize $\beta 2$-microglobulin-free, but not intact HLA heterodimers. HLA (2016) 87:356-66. doi:10.1111/tan.12775

261. Johnston O, Cassidy H, O'Connell S, O’Riordan A, Gallagher W, Maguire PB, et al. Identification of $\beta 2$-microglobulin as a urinary biomarker for chronic allograft nephropathy using proteomic methods. Proteomics Clin Appl (2011) 5:422-31. doi:10.1002/prca.201000160

262. Cassidy H, Slyne J, O’Kelly P, Traynor C, Conlon PJ, Johnston O, et al. Urinary biomarkers of chronic allograft nephropathy. Proteomics Clin Appl (2015) 9:574-85. doi:10.1002/prca.201400200

263. Schaub S, Rush D, Wilkins J, Gibson IW, Weiler T, Sangster K, et al. Proteomic-based detection of urine proteins associated with acute renal allograft rejection. J Am Soc Nephrol (2004) 15:219-27. doi:10.1097/01. ASN.0000101031.52826.BE

264. Schaub S, Wilkins JA, Antonovici M, Krokhin O, Weiler T, Rush D, et al. Proteomic-based identification of cleaved urinary beta2-microglobulin as a potential marker for acute tubular injury in renal allografts. Am J Transplant (2005) 5:729-38. doi:10.1111/j.1600-6143.2005.00766.x

265. Oetting WS, Rogers TB, Krick TP, Matas AJ, Ibrahim HN. Urinary beta2-microglobulin is associated with acute renal allograft rejection. Am J Kidney Dis (2006) 47:898-904. doi:10.1053/j.ajkd.2006.01.034

266. Zhang Y, Oetting WS, Harvey SB, Stone MD, Monkkonen T, Matas AJ, et al. Urinary peptide patterns in native kidneys and kidney allografts. Transplantation (2009) 87:1807-13. doi:10.1097/TP.0b013e3181a66595

267. Donadio C, Puccini R, Lucchesi A, Giordani R, Rizzo G. Urinary excretion of proteins and tubular enzymes in renal transplant patients. Ren Fail (1998) 20:707-15. doi:10.3109/08860229809045167

268. Wakabayashi K, Inokuma S, Matsubara E, Onishi K, Asashima H, Nakachi S, et al. Serum $\beta 2$-microglobulin level is a useful indicator of disease activity and hemophagocytic syndrome complication in systemic lupus erythematosus and adult-onset Still's disease. Clin Rheumatol (2013) 32:999-1005. doi:10.1007/s10067-013-2220-8

269. Yoo C, Yoon DH, Suh C. Serum beta-2 microglobulin in malignant lymphomas: an old but powerful prognostic factor. Blood Res (2014) 49:148-53. doi:10.5045/br.2014.49.3.148

270. Anders H-J, Vielhauer V. Renal co-morbidity in patients with rheumatic diseases. Arthritis Res Ther (2011) 13:222. doi:10.1186/ar3256

271. Chiu H-Y, Huang H-L, Li C-H, Chen H-A, Yeh C-L, Chiu S-H, et al. Increased risk of chronic kidney disease in rheumatoid arthritis associated with cardiovascular complications - a national population-based cohort study. PLoS One (2015) 10:e0136508. doi:10.1371/journal.pone.0136508

272. Kronbichler A, Mayer G. Renal involvement in autoimmune connective tissue diseases. BMC Med (2013) 11:95. doi:10.1186/1741-7015-11-95

273. Yoo C, Yoon DH, Kim S, Huh J, Park C-S, Park C-J, et al. Serum beta-2 microglobulin as a prognostic biomarker in patients with mantle cell lymphoma. Hematol Oncol (2016) 34:22-7. doi:10.1002/hon.2188

274. Seo S, Hong JY, Yoon S, Yoo C, Park JH, Lee JB, et al. Prognostic significance of serum beta- 2 microglobulin in patients with diffuse large B-cell lymphoma in the rituximab era. Oncotarget (2016) 7:76934-43. doi:10.18632/ oncotarget. 12734

275. Tsimberidou A-M, Kantarjian HM, Wen S, O’Brien S, Cortes J, Wierda WG, et al. The prognostic significance of serum $\beta 2$ microglobulin levels in acute myeloid leukemia and prognostic scores predicting survival: analysis of 1,180 patients. Clin Cancer Res (2008) 14:721-30. doi:10.1158/1078-0432. CCR-07-2063

276. von Hohenstaufen KA, Conconi A, de Campos CP, Franceschetti S, Bertoni F, Margiotta Casaluci G, et al. Prognostic impact of monocyte count at 
presentation in mantle cell lymphoma. Br J Haematol (2013) 162:465-73. doi:10.1111/bjh.12409

277. Wang Q, Qin Y, Zhou S, He X, Yang J, Kang S, et al. Prognostic value of pretreatment serum beta-2 microglobulin level in advanced classical Hodgkin lymphoma treated in the modern era. Oncotarget (2016) 7:72219-28. doi:10.18632/oncotarget.12663

278. Coutinho R, Lobato J, Esteves S, Carvalho S, Pierdomenico F, Bernardo P, et al. The NCCN-IPI helps to identify very high-risk patients with DLBCL and can be improved by other independent clinical factors including bulky disease and beta2-microglobulin. Blood (2015) 126:3888-3888.

279. Kanemasa Y, Shimoyama T, Sasaki Y, Tamura M, Sawada T, Omuro Y, et al. Beta-2 microglobulin as a significant prognostic factor and a new risk model for patients with diffuse large B-cell lymphoma. Hematol Oncol (2016). doi:10.1002/hon.2312

280. Rossi D, Fangazio M, De Paoli L, Puma A, Riccomagno P, Pinto V, et al. Beta2 -microglobulin is an independent predictor of progression in asymptomatic multiple myeloma. Cancer (2010) 116:2188-200. doi:10.1002/cncr.24959

281. Rajkumar SV, Fonseca R, Lacy MQ, Witzig TE, Lust JA, Greipp PR, et al. Beta2-microglobulin and bone marrow plasma cell involvement predict complete responders among patients undergoing blood cell transplantation for myeloma. Bone Marrow Transplant (1999) 23:1261-6. doi:10.1038/ sj.bmt. 1701787

282. Stella-Holowiecka B, Czerw T, Holowiecka-Goral A, Giebel S, Wojnar J, Holowiecki J. Beta-2-microglobulin level predicts outcome following autologous hematopoietic stem cell transplantation in patients with multiple myeloma. Transplant Proc (2007) 39:2893-7. doi:10.1016/j.transproceed. 2007.08.052

283. Palumbo A, Avet-Loiseau H, Oliva S, Lokhorst HM, Goldschmidt H, Rosinol L, et al. Revised international staging system for multiple myeloma: a report from International Myeloma Working Group. J Clin Oncol (2015) 33:2863. doi:10.1200/JCO.2015.61.2267

284. García de Veas Silva JL, Bermudo Guitarte C, Menéndez Valladares P, Rojas Noboa JC, Kestler K, Duro Millán R. Prognostic value of serum free light chains measurements in multiple myeloma patients. PLoS One (2016) 11:e0166841. doi:10.1371/journal.pone.0166841

285. Rajkumar SV. Myeloma today: disease definitions and treatment advances. Am J Hematol (2016) 91:90-100. doi:10.1002/ajh.24236

286. Papanikolaou X, Alapat D, Rosenthal A, Stein C, Epstein J, Owens R, et al. The flow cytometry-defined light chain cytoplasmic immunoglobulin index and an associated 12-gene expression signature are independent prognostic factors in multiple myeloma. Leukemia (2015) 29:1713-20. doi:10.1038/ leu. 2015.65

287. van Rhee F, Bolejack V, Hollmig K, Pineda-Roman M, Anaissie E, Epstein J, et al. High serum-free light chain levels and their rapid reduction in response to therapy define an aggressive multiple myeloma subtype with poor prognosis. Blood (2007) 110:827-32. doi:10.1182/blood-2007-01-067728

288. Park S, Han B, Kim K, Kim SJ, Jang JH, Kim WS, et al. Renal Insufficiency in newly-diagnosed multiple myeloma: analysis according to International Myeloma Working Group consensus statement. Anticancer Res (2014) 34:4299-306.

289. Chen C, Puvvada S. Prognostic factors for chronic lymphocytic leukemia. Curr Hematol Malig Rep (2016) 11:37-42. doi:10.1007/s11899-015-0294-x

290. Gentile M, Cutrona G, Neri A, Molica S, Ferrarini M, Morabito F. Predictive value of $\beta 2$-microglobulin ( $\beta 2-\mathrm{m})$ levels in chronic lymphocytic leukemia since Binet A stages. Haematologica (2009) 94:887-8. doi:10.3324/ haematol.2009.005561

291. Rossi D, Zucchetto A, Rossi FM, Capello D, Cerri M, Deambrogi C, et al. CD49d expression is an independent risk factor of progressive disease in early stage chronic lymphocytic leukemia. Haematologica (2008) 93:1575-9. doi:10.3324/haematol.13103

292. Thompson PA, O’Brien SM, Xiao L, Wang X, Burger JA, Jain N, et al. $\beta 2$ microglobulin normalization within 6 months of ibrutinib-based treatment is associated with superior PFS in CLL. Cancer (2016) 122:565-73. doi:10.1002/ cncr.29794

293. Høgdall E, Fung ET, Christensen IJ, Yip C, Nedergaard L, Engelholm SA, et al. Proteomic biomarkers for overall and progression-free survival in ovarian cancer patients. Proteomics Clin Appl (2010) 4:940-52. doi:10.1002/ prca.200900171
294. Sun J, Yang Z, Miao X, Zou Q, Li J, Liang L, et al. ATP5b and $\beta 2$ microglobulin are predictive markers for the prognosis of patients with gallbladder cancer. J Mol Histol (2015) 46:57-65. doi:10.1007/ s10735-014-9597-9

295. Zhang Y, Wang L, Ji P, Zhao G, Zhong G, Wang Z. Correlation of serum $\beta 2$-microglobulin levels with prostate-specific antigen, Gleason score, clinical stage, tumor metastasis and therapy efficacy in prostate cancer. Arch Med Res (2013) 44:259-65. doi:10.1016/j.arcmed.2013.03.008

296. Klein T, Levin I, Niska A, Koren R, Gal R, Schachter J, et al. Correlation between tumour and serum beta $2 \mathrm{~m}$ expression in patients with breast cancer. Eur J Immunogenet (1996) 23:417-23. doi:10.1111/j.1744-313X.1996. tb00132.x

297. Lucarelli G, Ditonno P, Bettocchi C, Vavallo A, Rutigliano M, Galleggiante V, et al. Diagnostic and prognostic role of preoperative circulating CA 15-3, CA 125 , and beta-2 microglobulin in renal cell carcinoma. Dis Markers (2014) 2014:e689795. doi:10.1155/2014/689795

298. Ueland FR. A perspective on ovarian cancer biomarkers: past, present and yet-to-come. Diagnostics (Basel) (2017) 7:14. doi:10.3390/diagnostics7010014

299. Ueland FR, Desimone CP, Seamon LG, Miller RA, Goodrich S, Podzielinski I, et al. Effectiveness of a multivariate index assay in the preoperative assessment of ovarian tumors. Obstet Gynecol (2011) 117:1289-97. doi:10.1097/AOG.0b013e31821b5118

300. Prizment AE, Linabery AM, Lutsey PL, Selvin E, Nelson HH, Folsom AR, et al. Circulating beta-2 microglobulin and risk of cancer: the atherosclerosis risk in communities study (ARIC). Cancer Epidemiol Biomarkers Prev (2016) 25:657-64. doi:10.1158/1055-9965.EPI-15-0849

301. Hermansen M-LF, Hummelshøj L, Lundsgaard D, Hornum L, Keller P, Fleckner J, et al. Increased serum $\beta 2$-microglobulin is associated with clinical and immunological markers of disease activity in systemic lupus erythematosus patients. Lupus (2012) 21:1098-104. doi:10.1177/0961203312447668

302. Candon S, Gottenberg JE, Bengoufa D, Chatenoud L, Mariette X. Quantitative assessment of antibodies to ribonucleoproteins in primary Sjögren syndrome: correlation with B-cell biomarkers and disease activity. Ann Rheum Dis (2009) 68:1208-12. doi:10.1136/ard.2008.095257

303. Gottenberg J, Busson M, Cohen-Solal J, Lavie F, Abbed K, Kimberly R, et al. Correlation of serum B lymphocyte stimulator and $B 2$ microglobulin with autoantibody secretion and systemic involvement in primary Sjögren's syndrome. Ann Rheum Dis (2005) 64:1050-5. doi:10.1136/ard.2004.030643

304. Gottenberg J-E, Seror R, Miceli-Richard C, Benessiano J, DevauchellePensec V, Dieude P, et al. Serum levels of beta2-microglobulin and free light chains of immunoglobulins are associated with systemic disease activity in Primary Sjögren's Syndrome. Data at enrollment in the prospective ASSESS cohort. PLoS One (2013) 8:e59868. doi:10.1371/journal.pone.0059868

305. Jiang T, Ding X, Lu W. The prognostic significance of beta2 microglobulin in patients with hemophagocytic lymphohistiocytosis. Dis Markers (2016) 2016:e1523959. doi:10.1155/2016/1523959

306. Amarante GBD, Zotin MC, Rocha E, Delgado AG Jr, Leite M Jr, Gomes CP. Renal tubular dysfunction in patients with primary Sjögren syndrome. Clin Nephrol (2014) 81:185-91. doi:10.5414/CN108142

307. Neirynck N, Eloot S, Glorieux G, Barreto DV, Barreto FC, Liabeuf S, et al. Estimated glomerular filtration rate is a poor predictor of the concentration of middle molecular weight uremic solutes in chronic kidney disease. PLoS One (2012) 7:e44201. doi:10.1371/journal.pone.0044201

308. Stevens LA, Coresh J, Schmid CH, Feldman HI, Froissart M, Kusek J, et al. Estimating GFR using serum cystatin C alone and in combination with serum creatinine: a pooled analysis of 3418 individuals with CKD. Am J Kidney Dis (2008) 51:395-406. doi:10.1053/j.ajkd.2007.11.018

309. Argyropoulos C, Unruh ML. Analysis of time to event outcomes in randomized controlled trials by generalized additive models. PLoS One (2015) 10:e0123784. doi:10.1371/journal.pone.0123784

310. Bhatt L, Horgan CP, Walsh M, McCaffrey MW. The hereditary hemochromatosis protein HFE and its chaperone beta2-microglobulin localise predominantly to the endosomal-recycling compartment. Biochem Biophys Res Commun (2007) 359:277-84. doi:10.1016/j.bbrc.2007.05.100

311. Ye L, Liu X, Rout SN, Li Z, Yan Y, Lu L, et al. The MHC class II-associated invariant chain interacts with the neonatal $\mathrm{Fc}$ gamma receptor and modulates its trafficking to endosomal/lysosomal compartments. J Immunol (2008) 181:2572-85. doi:10.4049/jimmunol.181.4.2572 
312. Ando M, Shibuya A, Tsuchiya K, Akiba T, Nitta K. Reduced capacity of mononuclear cells to synthesize cytokines against an inflammatory stimulus in uremic patients. Nephron Clin Pract (2006) 104:c113-9. doi:10.1159/000094446

313. Lonnemann G, Novick D, Rubinstein M, Dinarello CA. Interleukin-18, interleukin-18 binding protein and impaired production of interferon-gamma in chronic renal failure. Clin Nephrol (2003) 60:327-34. doi:10.5414/CNP60327

314. Ahmed AT, Karter AJ. Tuberculosis in California dialysis patients. Int J Tuberc Lung Dis (2004) 8:341-5.

315. Chia S, Karim M, Elwood RK, FitzGerald JM. Risk of tuberculosis in dialysis patients: a population-based study. Int J Tuberc Lung Dis (1998) 2:989-91.

316. Chou KJ, Fang HC, Bai KJ, Hwang SJ, Yang WC, Chung HM. Tuberculosis in maintenance dialysis patients. Nephron (2001) 88:138-43. doi:10.1159/ 000045974

317. Dalrymple LS, Go AS. Epidemiology of acute infections among patients with chronic kidney disease. Clin J Am Soc Nephrol (2008) 3:1487-93. doi:10.2215/ CJN.01290308

318. Maisonneuve P, Agodoa L, Gellert R, Stewart J, Buccianti G, Lowenfels A, et al. Cancer in patients on dialysis for end-stage renal disease: an international collaborative study. Lancet (1999) 354:93-9. doi:10.1016/S01406736(99)06154-1

319. Stengel B. Chronic kidney disease and cancer: a troubling connection. J Nephrol (2010) 23:253-62.

320. Vajdic CM, McDonald SP, McCredie MRE, van Leeuwen MT, Stewart JH, Law $\mathrm{M}$, et al. Cancer incidence before and after kidney transplantation. JAMA (2006) 296:2823-31. doi:10.1001/jama.296.23.2823

321. Yanik EL, Clarke CA, Snyder JJ, Pfeiffer RM, Engels EA. Variation in cancer incidence among patients with ESRD during kidney function and nonfunction intervals. J Am Soc Nephrol (2016) 27:1495-504. doi:10.1681/ ASN.2015040373

322. Butler AM, Olshan AF, Kshirsagar AV, Edwards JK, Nielsen ME, Wheeler SB, et al. Cancer incidence among US Medicare ESRD patients receiving hemodialysis, 1996-2009. Am J Kidney Dis (2015) 65:763-72. doi:10.1053/j.ajkd. 2014.12.013

323. Shang W, Huang L, Li L, Li X, Zeng R, Ge S, et al. Cancer risk in patients receiving renal replacement therapy: a meta-analysis of cohort studies. $\mathrm{Mol}$ Clin Oncol (2016) 5:315-25. doi:10.3892/mco.2016.952

324. Jahn B, Betz M, Deppisch R, Janssen O, Hänsch GM, Ritz E. Stimulation of beta 2-microglobulin synthesis in lymphocytes after exposure to Cuprophan dialyzer membranes. Kidney Int (1991) 40:285-90. doi:10.1038/ki.1991.212
325. Schoels M, Jahn B, Hug F, Deppisch R, Ritz E, Hänsch GM. Stimulation of mononuclear cells by contact with cuprophan membranes: further increase of beta 2-microglobulin synthesis by activated late complement components. Am J Kidney Dis (1993) 21:394-9. doi:10.1016/S02726386(12)80267-8

326. Campistol JM, Molina R, Bernard DB, Rodriguez R, Mirapeix E, MunozGomez JM, et al. Synthesis of beta 2-microglobulin in lymphocyte culture: role of hemodialysis, dialysis membranes, dialysis-amyloidosis, and lymphokines. Am J Kidney Dis (1993) 22:691-9. doi:10.1016/ S0272-6386(12)80432-X

327. Zingraff J, Beyne P, Ureña P, Uzan M, Man NK, Descamps-Latscha B, et al. Influence of haemodialysis membranes on beta 2-microglobulin kinetics: in vivo and in vitro studies. Nephrol Dial Transplant (1988) 3:284-90.

328. Haufe CC, Eismann U, Deppisch RM, Stein G. Expression of beta2microglobulin and c-fos mRNA: is there an influence of high- or low-flux dialyzer membranes? Kidney Int Suppl (2001) 78:S177-81. doi:10.1046/j. 1523-1755.2001.07816.x

329. Zaoui PM, Stone WJ, Hakim RM. Effects of dialysis membranes on beta 2-microglobulin production and cellular expression. Kidney Int (1990) 38:962-8. doi:10.1038/ki.1990.298

330. Traut M, Haufe CC, Eismann U, Deppisch RM, Stein G, Wolf G. Increased binding of beta-2-microglobulin to blood cells in dialysis patients treated with high-flux dialyzers compared with low-flux membranes contributed to reduced beta-2-microglobulin concentrations. Results of a cross-over study. Blood Purif (2007) 25:432-40. doi:10.1159/000110069

331. Vanholder R, Abou-Deif O, Argiles A, Baurmeister U, Beige J, Brouckaert P, et al. The role of EUTox in uremic toxin research. Semin Dial (2009) 22:323-8. doi:10.1111/j.1525-139X.2009.00574.x

Conflict of Interest Statement: The authors declare that the research was conducted in the absence of any commercial or financial relationships that could be construed as a potential conflict of interest.

Copyright $(2017$ Argyropoulos, Chen, Ng, Roumelioti, Shaffi, Singh and Tzamaloukas. This is an open-access article distributed under the terms of the Creative Commons Attribution License (CC BY). The use, distribution or reproduction in other forums is permitted, provided the original author(s) or licensor are credited and that the original publication in this journal is cited, in accordance with accepted academic practice. No use, distribution or reproduction is permitted which does not comply with these terms. 